\title{
Diabetic nephropathy
}

\section{Themis Zelmanovitz*1,2, Fernando Gerchman1, Amely PS Balthazar ${ }^{3}$, Fúlvio CS Thomazelli ${ }^{4}$, Jorge D Matos ${ }^{5}$ and Luís H Canani ${ }^{1,2}$}

\begin{abstract}
Address: ${ }^{1}$ Endocrine Division, Hospital de Clínicas de Porto Alegre, Universidade Federal do Rio Grande do Sul, Porto Alegre, Brazil, ${ }^{2}$ Universidade Federal do Rio Grande do Sul, Brazil, ${ }^{3}$ Universidade do Sul de Santa Catarina, Brazil, ${ }^{4}$ Medical School of Universidade Regional de Blumenau, Santa Catarina, Brazil and ${ }^{5}$ Universidade Federal de Santa Catarina, Brazil

Email: Themis Zelmanovitz* - themis.voy@terra.com.br; Fernando Gerchman - fgerchman@terra.com.br; Amely PS Balthazar - amelyps@hotmail.com; Fúlvio CS Thomazelli - fulvioth@terra.com.br; Jorge D Matos - jdmatos@mbox1.ufsc.br; Luís H Canani - luiscanani@yahoo.com

* Corresponding author
\end{abstract}

\section{Published: 2I September 2009}

Diabetology \& Metabolic Syndrome 2009, I:10 doi:10.1186/1758-5996-1-10
Received: 12 July 2009

Accepted: 21 September 2009

This article is available from: http://www.dmsjournal.com/content/I/I//0

(c) 2009 Zelmanovitz et al; licensee BioMed Central Ltd.

This is an Open Access article distributed under the terms of the Creative Commons Attribution License (http://creativecommons.org/licenses/by/2.0), which permits unrestricted use, distribution, and reproduction in any medium, provided the original work is properly cited.

\begin{abstract}
Diabetic nephropathy is the leading cause of chronic renal disease and a major cause of cardiovascular mortality. Diabetic nephropathy has been categorized into stages: microalbuminuria and macroalbuminuria. The cut-off values of micro- and macroalbuminuria are arbitrary and their values have been questioned. Subjects in the upper-normal range of albuminuria seem to be at high risk of progression to micro- or macroalbuminuria and they also had a higher blood pressure than normoalbuminuric subjects in the lower normoalbuminuria range. Diabetic nephropathy screening is made by measuring albumin in spot urine. If abnormal, it should be confirmed in two out three samples collected in a three to six-months interval. Additionally, it is recommended that glomerular filtration rate be routinely estimated for appropriate screening of nephropathy, because some patients present a decreased glomerular filtration rate when urine albumin values are in the normal range. The two main risk factors for diabetic nephropathy are hyperglycemia and arterial hypertension, but the genetic susceptibility in both type I and type 2 diabetes is of great importance. Other risk factors are smoking, dyslipidemia, proteinuria, glomerular hyperfiltration and dietary factors. Nephropathy is pathologically characterized in individuals with type I diabetes by thickening of glomerular and tubular basal membranes, with progressive mesangial expansion (diffuse or nodular) leading to progressive reduction of glomerular filtration surface. Concurrent interstitial morphological alterations and hyalinization of afferent and efferent glomerular arterioles also occur. Podocytes abnormalities also appear to be involved in the glomerulosclerosis process. In patients with type 2 diabetes, renal lesions are heterogeneous and more complex than in individuals with type I diabetes. Treatment of diabetic nephropathy is based on a multiple risk factor approach, and the goal is retarding the development or progression of the disease and to decrease the subject's increased risk of cardiovascular disease. Achieving the best metabolic control, treating hypertension $(<130 / 80 \mathrm{mmHg})$ and dyslipidemia (LDL cholesterol $<100 \mathrm{mg} / \mathrm{dl})$, using drugs that block the renin-angiotensin-aldosterone system, are effective strategies for preventing the development of microalbuminuria, delaying the progression to more advanced stages of nephropathy and reducing cardiovascular mortality in patients with diabetes.
\end{abstract}




\section{Review}

Diabetic nephropathy (DN) is the leading cause of chronic renal disease in patients starting renal replacement therapy [1] in the United States as well as in Brazil [2]. It is associated with increased cardiovascular mortality $[2,3]$. DN has been classically defined as increased protein excretion in urine. Early stage is characterized by a small increase in urinary albumin excretion (UAE), also called microalbuminuria or incipient DN [4-7]. More advanced disease is defined by the presence of macroalbuminuria or proteinuria. The latter is classically named overt DN. In most cases, proteinuria and decreased glomerular filtration rate (GFR) occur in parallel. Traditionally, GFR has been expected to decrease when proteinuria is established, but not before. However, it is clear today that some subjects could have DN without increased UAE $[8,9]$. About $10 \%$ of subjects with type 2 diabetes mellitus (DM) will have low GFR without microor macroalbuminuria [10]. This was also observed among patients with type $1 \mathrm{DM}$ and microalbuminuria [11].

The prevalence of DN varies according to ethnicity: it is higher in African-Americans, Asians and Native-Americans than in Caucasians [1,12]. African-Brazilians are more susceptible to progress to end-stage renal disease (ESRD) than people of European ancestry, but there appears to be a similar prevalence of micro- or macroalbuminuria [13].

Among patients starting renal replacement therapy, the incidence of DN continued to rise from 1991 to 2001 [1]. This observation could not be attributed to older age or DM prevalence. From 1984-1996, the incidence of ESRD treatment attributable to DM (ESRD-DM) per 100,000 diabetic population increased in all age groups. However, in 1997-2002, ESRD-DM incidence decreased for people younger than 65 years (by 28\% for those younger than 45 years and by $19 \%$ for those aged $45-64$ years), did not change for those aged 65-74 years, and increased only among persons aged 75 years or older (by 10\% from 350.3 to 383.7) http://www.cdc.gov/mmwr/preview/ mmwrhtml/mm5443a2.htm. Although people younger than 65 years had the highest incidence of ESRD-DM prior to 1990, by 1999 their incidence was lower than in the older ones http://www.cdc.gov/diabetes/statistics/ esrd/fig6.htm.

The increased incidence of ESRD attributable to DM suggests that other factors are involved in the etiology of $\mathrm{DN}$, since a putative improvement in blood pressure (BP) levels, increased use of angiotensin converting enzyme (ACE) inhibitors and better glucose control due to lower glycemic targets have been frequent in recent years.

\section{Stages}

According to UAE values, DN has been didactically categorized into stages. The cutoff values used [14] to characterize these stages are described in Table 1.

Although microalbuminuria is considered a risk factor for the development of macroalbuminuria, not all patients progress to this stage, and some may regress to normoalbuminuria $[15,16]$. The initial studies suggested that about $80 \%$ of type 1 diabetic patients with microalbuminuria would progress to proteinuria over a period of 6 to 14 years [4-6]. More recent studies suggest that only 30 to $45 \%$ of microalbuminuric patients will progress to proteinuria over 10 years of follow-up [15]. In fact, some of them will present regression to normoalbuminuria. This might be the result of more intensive glucose and $\mathrm{BP}$ control strategies employed in the last decade than in the initial studies. This regression of microalbuminuria is more frequent among subjects with short duration of microalbuminuria, glicohemoglobin A1c (HbA1c) below 8\%, systolic $\mathrm{BP}<115 \mathrm{~mm} \mathrm{Hg}$, and favorable lipid profile (serum total cholesterol $<198 \mathrm{mg} / \mathrm{dl}$ and triglycerides $<145 \mathrm{mg} / \mathrm{dl}$ ). Independent of the role as a prognostic factor for macroalbuminuria, the presence of microalbuminuria, reflecting a state of generalized endothelial dysfunction, is a risk factor for cardiovascular disease and mortality $[17,18]$.

The cut-off values of urinary albumin to define the stages of DN are arbitrary (Table 1). On the one hand, not all

Table I: Diabetic nephropathy stages based on urinary albumin excretion

\begin{tabular}{|c|c|c|c|c|}
\hline \multirow[t]{2}{*}{ Stage } & \multirow{2}{*}{$\begin{array}{l}\text { Urine with marked time } \\
\qquad(\mu \mathrm{g} / \mathrm{min})^{*}\end{array}$} & \multirow{2}{*}{$\begin{array}{l}\text { 24-hour urine } \\
\text { (mg/24 h)* }\end{array}$} & \multicolumn{2}{|c|}{ Random urine sample } \\
\hline & & & $\begin{array}{l}\text { Albumin concentration } \\
(\mathrm{mg} / \mathrm{l})^{* *}\end{array}$ & $\begin{array}{c}\text { Albumin/creatinine ratio } \\
\text { (mg/g)* }\end{array}$ \\
\hline Normoalbuminuria & $<20$ & $<30$ & $<17$ & $<30$ \\
\hline Microalbuminuria & $20--199$ & $30--299$ & 17 a 173 & $30--299$ \\
\hline Macroalbuminuria & $\geq 200$ & $\geq 300$ & $\geq 174$ & $\geq 300$ \\
\hline
\end{tabular}

* Values according to the American Diabetes Association

** Gross et al., Diabetes Care 2005. 
subjects will progress to overt $\mathrm{DN}$, and some might even regress as stated before. On the other hand subjects in the upper-normal range of albuminuria seem to be at high risk for complications. In patients with type $2 \mathrm{DM}$, the progression to micro- or macroalbuminuria is more frequent in individuals whose baseline UAE was normal but above $2.5 \mathrm{mg} / 24 \mathrm{~h}$ [19]. Furthermore, in another study after 10 years of follow-up, patients with type $2 \mathrm{DM}$ and UAE values above $10 \mu \mathrm{g} / \mathrm{min}$ were at 29 times higher risk of developing DN [20]. Similar results were observed in patients with type $1 \mathrm{DM}$ [21]. Another interesting observation is that patients with type $2 \mathrm{DM}$ and UAE in the upper-normal range had higher BP than normoalbuminuric patients in the lower UAE range [22]. This favors the concept that UAE is a continuum similar to what has been demonstrated for BP and cholesterol levels.

In the microalbuminuric stage, no decline in GFR is expected. Once the subject has developed macroalbuminuria, the expected GFR decline is $1.2 \mathrm{ml} / \mathrm{min} / \mathrm{month}$ in type $1 \mathrm{DM}$ [23]. This could be decreased by BP treatment. In type $2 \mathrm{DM}$, the rate of GFR decline is less predictable. A mean decline of approximately $0.5 \mathrm{ml} / \mathrm{min} /$ month [24] has been described, but in some patients GFR may remain stable for long periods of time [25]. The greater GFR decline is associated with more advanced diabetic glomerulopathy and worse metabolic control [26].

\section{Screening and Diagnosis}

The first step in screening for DN is to measure albumin in an isolated urine sample [27]. The results of albuminuria in an isolated sample can be expressed as albumin concentration $(\mathrm{mg} / \mathrm{l})$ or as albumin/creatinine ratio $(\mathrm{mg} / \mathrm{g})$ [28]. Although albumin concentration may be influenced by urine dilution/concentration, this measure appears to be the best choice, considering its cost and accuracy [29]. Every abnormal albuminuria test should be confirmed in two of three samples collected at a three to six-months interval, due to the daily variability of UAE [30]. Screening should not be performed under conditions that may increase UAE, such as hematuria, acute systemic diseases or fever, vigorous physical exercise, poor glycemic control, uncontrolled arterial hypertension and decompensated cardiac failure [31]. Bacteriuria had also been considered a factor that could interfere in the measure of urinary albumin [31-33]; but in a recent study this finding was not confirmed, suggesting that it is not necessary to exclude bacteriuria to measure albuminuria [34].

In situations in which UAE measurement is not available, semiquantitative dipstick measurements of albuminuria (for instance: Micral $^{\circledast}$ Test II) can be used, although these tests are less accurate [29].
The quantitative methods most commonly used to measure albuminuria are immunoturbidimetry, immunonephelometry and radioimmunoassay. However, recently it has been observed that an appreciable quantity of albumin is not detected by routine immunoassay methods, defined as non-immunoreactive fraction, which results in an underestimate of UAE [35-37]. On the other hand the HPLC (high performance liquid chromatography) method measures the immunoreactive and non-immunoreactive fractions which compose the total intact albumin, allowing the detection of earlier albumin elevations $[37,38]$. However, this method can overestimate UAE as observed in some community studies, possibly due to the fact that albumin peaks measured using this method can be confounded with other proteins [39]. Therefore, the significance of total intact albumin, both to diagnose $\mathrm{DN}$, and for its association with cardiovascular disease has not yet been well established.

DN screening must be performed when DM is diagnosed in patients with type $2 \mathrm{DM}$, since these individuals may have had a silent form of DM for some time already. For patients with type $1 \mathrm{DM}$, it is recommended that screening be performed beginning in the fifth year after DM diagnosis or earlier if the DM is chronically poorly compensated, or if the patient is an adolescent. In all cases, if albuminuria is normal, screening must be repeated annually [27].

Although the measurement of albuminuria is essential to diagnose DN, there are some patients who present decreased GFR when UAE values are normal. Based on this, the classification of the National Kidney Foundation can also be used to stage chronic kidney disease in these patients (Table 2) [27]. It is recommended that GFR be routinely estimated for appropriate screening of DN. GFR can be measured using specific techniques such as inulin clearance, 51Cr-EDTA, 125I-iothalamate, and iohexol. However, in clinical practice, GFR is estimated by equations that take into account serum creatinine concentration and some or all of the following variables: age, sex, body weight and race. The equation recommended by the National Kidney Foundation is that of the study on Modification of Diet in Renal Disease (MDRD): GFR (ml/min/ $\left.1.73 \mathrm{~m}^{2}\right)=186 \times\left[\right.$ serum creatinine $(\mathrm{mg} / \mathrm{dl})^{-1,154} \times$ age (years) ${ }^{-0,203} \times(0.742$ if a woman $) \times(1.21$ if African-American)]. If the creatinine measurement method is calibrated, the formula should use factor "175" in place of the value "186". The Cockroft-Gault formula, creatinine depuration $(\mathrm{ml} / \mathrm{min})=[140-$ age $($ years $)] \times$ weight $(\mathrm{kg}) /$ $[72 \times$ serum creatinine $(\mathrm{mg} / \mathrm{dl})] \times 0.85$ (if a woman) is less precise [40]. The reference values of GFR for young individuals are 90 to $130 \mathrm{ml} / \mathrm{min} / 1.73 \mathrm{~m}^{2}$, with the reduction of these values as age increases, in the order of $10 \mathrm{ml} /$ $\mathrm{min} /$ decade after the age of 50 years [41]. 
Table 2: Chronic kidney disease stages

\begin{tabular}{ccc}
\hline Stage & Description & GFR (ml/min/l.73 $\left.\mathbf{~ m}^{2}\right)$ \\
\hline 1 & Renal damage* with GFR N or $\uparrow$ & 290 \\
2 & Renal damage* with GFR slightly $\downarrow$ & $60-89$ \\
3 & GFR moderately $\downarrow$ & $30-59$ \\
4 & GFR severely $\downarrow$ & $15-29$ \\
5 & End stage chronic renal failure & $<15$ or dialysis \\
\hline
\end{tabular}

*Renal damage is defined by abnormalities in the urine and blood tests, imaging exams or in pathology

GFR = glomerular filtration rate

Serum creatinine concentration should not be used as an isolated index for the evaluation of renal function, since its measure is affected by other factors besides GFR itself, such as tubular secretion, extrarenal generation and protein ingestion.

\section{Special Situations}

Patients with micro- or macroalbuminuria, after the confirmation of diagnosis ( 2 measurements), should undergo a complete evaluation concerning differential diagnosis and assessment of renal function. DN is associated with several other conditions that need to be addressed making the management of these patients very complex. However this is not within the scope of the present manuscript and a detailed approach could be found in a recent review [30].

Diabetic patients can have other kidney diseases. The differential diagnosis is usually based on the history, physical examination, laboratory evaluation and kidney imaging. Renal biopsy has only been recommended in special situations. In the presence of micro or microalbuminuria and diabetic retinopathy in a patient with long term DM (e.g. $>10$ years) the assumption that DM is causing the renal disease is generally correct. Conversely, in diabetic patients with type $2 \mathrm{DM}$ with a fast increment in albuminuria and in patients with type 1 DM where macroalbuminuria develop in the absence of diabetic retinopathy a differential diagnosis should be carried out. However, in type 2 diabetic patients the time of DM onset is usually unknown and retinopathy could be absent in a significant proportion (28\%) of patients with albuminuria [42]. In summary, absent retinopathy, short duration of DM and faster decline in GFR and/or albuminuria increment are indications to suspect of nondiabetic renal disease [43]. If after a non-invasive evaluation the diagnosis is still unclear, a kidney biopsy should be discussed. In type $2 \mathrm{DM}$ the prevalence of nondiabetic renal disease could vary from 12 to $38 \%[42,44,45]$. All the kidney biopsy data are derived from retrospective studies. The differences in the prevalence of non-diabetic lesion observed in the studies probably reflect different criteria used to indicate renal biopsies. In one study, subjects with type 2 $\mathrm{DM}$, gross proteinuria ( $>1 \mathrm{~g}$ ) without retinopathy, and hematuria and no retinopathy, 19\% of patients with confirmed DN had another glomerulopathy associated [45]. In this study, patients without diabetic glomerulosclerosis had a better prognosis than those with diabetic glomerulosclerosis [45]. Another aspect that needs to be addressed is that it is not clear if there is additional benefit of detecting other nephropathies in the management of these patients.

\section{Risk Factors}

The two main risk factors for DN are hyperglycemia and arterial hypertension. However, DN develops in only about $40 \%$ of patients, even in the presence of hyperglycemia and elevated BP for long periods of time. This observation raised the concept that $\mathrm{DN}$ will develop only in a susceptible subset of patients [46-48]. Furthermore, family studies have confirmed a genetic contribution for the development of DN in both type 1 and type 2 DM [4953]. Once DN is present, progression factors may act, favoring evolution to more advanced stages. There is evidence that some factors involved in the development of proteinuria are also common to the loss of GFR, but others are unique to each one of them [54].

\section{Hyperglycemia}

Hyperglycemia is a significant risk factor for the development of microalbuminuria, both in type 1 and in type 2 DM $[21,55,56]$. A reduction of $1 \%$ in HbA1c is associated with a $37 \%$ decrease in microvascular endpoints [57]. In the presence of micro- and macroalbuminuria the role of metabolic control is less defined, even though some studies showed a deleterious effect of high glucose levels on GFR $[58,59]$. Moreover, it was demonstrated that pancreas transplantation reversed renal damage in type $1 \mathrm{DM}$ patients with mild to advanced DN lesions [60]. Recently a large trial also reinforced the importance of intensive treatment of DM to decrease the microvascular complications [61].

\section{Arterial Hypertension}

Arterial hypertension is a main risk factor for the development of DN $[56,62]$, and probably the best known relevant factor related to its progression. Analysis of UKPDS showed that every $10 \mathrm{mmHg}$ reduction in systolic BP is 
associated with a $13 \%$ reduction in the risk of microvascular complications, with the smallest risk among those patients with systolic BP $<120 \mathrm{~mm} \mathrm{Hg}$ [63].

\section{Smoking}

Smoking is a risk factor for DN $[19,56]$ and might contribute to its progression [64]. Although some studies did not confirm these observations $[55,59,65]$, it is strongly recommended to quit smoking in any phase of DN, also aiming to reduce the associated cardiovascular and cancer risk.

\section{Dyslipidemia}

In type $2 \mathrm{DM}$, elevated serum cholesterol is a risk factor for the development of DN $[55,56]$. In type $1 \mathrm{DM}$ patients increased serum triglycerides, total and LDL-cholesterol were associated with micro- and macroalbuminuria $[66,67]$. High serum cholesterol also seems to be a risk factor for GFR loss in macroalbuminuric type 1 diabetic subjects [68].

\section{Proteinuria}

Proteinuria itself could lead to progression of DN. Proteinuria $>2 \mathrm{~g} / 24 \mathrm{~h}$ is associated with a greater risk of ESRD [69]. Increased leakage of albumin may induce glomerular damage probably through activation of inflammatory cascades [70]. This would be a reason to target decreased urinary albumin excretion in DN treatment.

\section{Glomerular hyperfiltration}

Elevated GFR values are present in about one third of type 2 DM patients $[71,72]$ and theoretically it could cause DN due to glomerular damage [73]. Studies led to controversial findings regarding its role as a risk factor for the development of DN $[20,71,74]$. Type 2 DM patients with a single-kidney more often present increased UAE levels $[75,76]$. On the other hand, type $1 \mathrm{DM}$ patients with only one kidney do not have a more aggressive disease [77]. Glomerular hyperfiltration probably plays a small role, if any, in the development of DN [78].

\section{Dietary factors}

Increased dietary protein intake seems to be associated with the presence of higher UAE values, at least in patients with type $1 \mathrm{DM}[79]$. In patients with type $2 \mathrm{DM}$ this association has not been documented. The source of proteins in the diet also seems to be related to the presence of DN. A higher intake of fish protein is related to a lower risk of microalbuminuria in type 1 DM patients [80]. The mechanisms involved in these findings are unknown but probably related to hemodynamic factors [81].

Regarding the dietary lipid content, an association has been observed between the higher intake of saturated fat and the presence of microalbuminuria in patients with type 1 DM [82]. In patients with type 2 DM, very recently, it was observed that the presence of microalbuminuria was associated with the lower content of polyunsaturated fatty acids, especially those of vegetal origin [83]. In a study performed with patients with type 1 and type 2 DM, followed for 6 years, it was also demonstrated that those who evolved with regression of the DN presented a higher intake of polyunsaturated fatty acids and a lower intake of saturated fatty acids [84].

\section{Genetic risk factors}

The exact genetic model underlying DN susceptibility is uncertain, but theoretically few genes with a major contribution and some with minor interaction with the environment could cause DN $[47,48]$. Unfortunately, no gene with a major effect had been identified so far. The knowledge of which gene(s) predisposes to DN will allow the identification of patients at high risk for this complication, and adoption of preventive measures.

In genetic studies the clear definition of the phenotype, $\mathrm{DN}$, is very important. DN could be defined by different parameters: for instance, the presence of microalbuminuria, macroalbuminuria, ESRD or decreased GFR. Some genes probably are involved in the development of proteinuria, others with decline in GFR and some will be involved in both situations $[47,48]$. Therefore, a more comprehensive definition of DN used in the genetic studies is important to make the results more comparable.

A familial aggregation of DN has been demonstrated in studies of sibling-pairs $[49,53,85]$, parent-offspring pairs or studies of extended families $[51,52]$. One practical application of the studies with diabetic siblings is that the chance of having DN increases 2-3 times if the subject's sibling has DN when compared to the subject who has a normoalbuminuric sibling, either in type 1 or type 2 diabetes $[49,53]$.

Recent advances in technology make easier to look for regions in whole genome linked to different DN phenotypes [86-88]. This approach identified regions and putative genes not previously known to be associated with DN and it could raise new candidate genes. Moreover, new targets for drug development may come into sight, since some of the genes found are novel and have not been previously implicated in the pathogenesis of DN.

Association studies of candidate genes have been performed aiming to identify polymorphic variants associated with DN or with different degrees of renal disease. Often, genes that play a role in the expression of proteins that are related to the modulation of cytokines, proteins involved in the glycid and lipid metabolism, in the formation of extracellular matrix, in blood pressure homeosta- 
sis, and in insulin sensitivity, have been considered candidates for the development of DN $[9,30,89]$. However, the studies have not been successful in identifying genes that consistently show an association with DN. Replication studies have demonstrated conflicting results [90]. The evaluation of 360 thousand polymorphisms in patients with type $1 \mathrm{DM}$, with and without $\mathrm{DN}$, showed a total of 13 polymorphisms located at 4 loci in two independent cohorts of subjects strongly associated with the presence of DN [87]. Some of these polymorphisms are located in genes highly expressed in the kidney with DN, and its development over time [87].

Another approach that has been used to investigate the genetics of DN involves the study of microRNAs role on this process. These are non-encoding short RNAs that induce post-transcriptional protein modifications. Little is known about these molecules and their role in DN. In a study, microRNA mirR-192 expression was increased in the glomeruli of rodents with DM [91]. Their induction by TGF- $\beta$ in mesangial cells caused increased collagen synthesis and suggests that this type of molecule may be implicated in the development of DN, opening up a new prospect of research in elucidating the pathogenesis of this DM complication. The replication of this finding and this type of approach must be better explored in studied conducted in human beings.

As previously stated, Brazilians of African descent have more aggressive renal disease than people of European ancestry [13]. This could be due to several reasons, such as the presence of different risk factors, different access to medical attention, and socioeconomic differences. However, none of the assessed known risk factors were different between African and Europeans [13,92] make unclear an explanation for the different rates of DN between black and white subjects. Unfortunately, data on socioeconomic status were unavailable. An alternative explanation for this observation, but hard to prove, would be a different genetic susceptibility.

\section{Pathology}

DN in individuals with type $1 \mathrm{DM}$ is initially characterized by a thickening of the glomerular and tubular basal membrane, with progressive mesangial expansion leading to the progressive reduction of the glomerular filtration surface [93]. Concurrent interstitial morphological alterations also occur, as well as hyalinization of the afferent and efferent glomerular arterioles [93]. Mesangial expansion can be diffuse (diabetic glomerulosclerosis) or with areas of marked mesangial expansion, forming roundish and fibrillar zones, with nuclei in palisade (nodular glomerulosclerosis, Kimmelstiel-Wilson nodes). While mesangial expansion is the critical lesion which leads to progression to loss of renal function, damage to the tubu- lar glomerular junction, to the tubules and to the interstice determines progression to ESRD $[87,91]$.

Podocytes damage also appears to be involved in the glomerulosclerosis process. In a study conducted in Pima Indians, highly susceptible to developing $\mathrm{DN}$, a smaller number of podocytes per glomerulus was the greatest predictor of increased UAE and progression to clinical DN [93]. When this finding was present, normoalbuminuric individuals had a higher risk of progressing to renal disease than those who did not have a podocyte lesion [93]. In addition, nephrine, a protein synthesized by the podocyte and considered vital to the stability of the glomerular barrier, has its expression reduced in DN [94]. The administration of ACE inhibitors results in the expression of nephrine at levels similar to those of individuals with DM without DN [95].

In a subgroup of patients with DM, loss of renal function precedes the development of microalbuminuria. This group presents more advanced glomerular lesions than those that present microalbuminuria [93].

Renal lesions in individuals with type $2 \mathrm{DM}$ are more complex than in individuals with type $1 \mathrm{DM}$. The prevalence of a renal lesion that is non-typical for DM in individuals with type $2 \mathrm{DM}$ is high, reaching $10-30 \%$ of subjects with proteinuria $[91,93]$. In a minority, the histopathological aspects are similar to the typical lesion of subjects with type $1 \mathrm{DM}$. The rest presents only mild or absent DN, with or without tubulointerstitial alterations, arteriolar alterations or diffuse glomerulosclerosis [93]. The tubulopathy is possibly related to persistent hyperglycemia and changes related to age, atherosclerosis and arterial hypertension [91]. Despite the heterogeneity of the lesions and the impact of diseases such as arterial hypertension on individuals with type $2 \mathrm{DM}$, in a large cohort of individuals with type $2 \mathrm{DM}$, the severity of the lesions was correlated with the progression of DN and the velocity of GFR loss [26].

\section{Pathophysiological Mechanisms \\ Hemodynamic factors}

In an initial phase, DN is characterized by glomerular hyperfiltration due to a reduction in the resistance of the afferent and efferent glomerular arterioles, and consequent increased renal perfusion. Although the mechanisms that lead to glomerular hyperfiltration are unclear, obesity and the release of a number of proinflammatory factors and growth factors that occur in DM appear to have a role $[96,97]$. In a study performed by our group, the levels of endothelin 1 (ET-1), an important vasoconstrictor, were correlated with UAE, and its plasma levels were progressively higher according to the higher degree of DN [98]. This early defect in autoregulation of renal 
perfusion makes it easier for albumin to leak from capillaries to renal glomerulus, and leads to compensatory increase of mesangial matrix, thickening of the glomerular basement membrane and podocyte damage. Albuminuria also activates a series of inflammatory pathways through tubular cells and feeds this process [91]. In addition, the mechanical stress resulting from renal hyperperfusion induces the release of cytokines (TNF- $\alpha$ ), growth factors (VEGF, TGF- $\beta 1$ ), cholesterol and local triglycerides that induce the accumulation of proteins from extracellular matrix, leading to mesangial expansion and glomerulosclerosis. A reduction of TGF- $\beta 1$ by blocking the reninangiotensin-aldosterone system retards the progression of DN and preserves glomerular morphology [99].

\section{Hyperglycemia and advanced products of non-enzymatic glycosilation}

Persistent hyperglycemia is a strong risk factor for DN and causes the proliferation of mesangial cells and their matrix, as well as the thickening of the basement membrane. Hyperglycemia increases the expression of vascular endothelial growth factor (VEGF) in podocytes causing increased vascular permeability. Hyperglycemia also increases the generation of advanced products of nonenzymatic glycosilation of proteins through activation of aldol reductase pathway and protein kinase $\mathrm{C}$ (PKC). The final products of non-enzymatic glycosilation are bound to collagen and proteins that constitute the glomerular basement membrane and make the glomerular barrier more permeable to the passage of proteins, resulting in increased UAE [94,100-104].

\section{Cytokines}

A series of circulating markers of inflammation such as $\mathrm{C}$ reactive protein and interleukin 1, 6 and 18, and tumor necrosis factor are increased in DN and their levels correlate with albuminuria and progression to ESRD. In addition, hyperglycemia, TGF- $\beta 1$ and angiotensin II stimulate the secretion of VEGF, causing the production of endothelial nitric oxide, vasodilation and glomerular hyperfiltration [94]. Hyperglycemia, possibly mediated by oxidative stress, also induces angiotensin II to the synthesis of TGF$\beta$, type IV collagen and fibronectin, contributing to progressive glomeruloesclerosis [87].

Inflammatory factors are also involved in the development of tubulointerstitial lesion, and appear to lead to accumulation of macrophages in the tubular interstice in animal models designed to study DN. Macrophages also produce free radicals, inflammatory cytokines and proteases that induce tubular damage [91]. Furthermore, glomerular and renal cells also produce a series of inflammatory factors when they are exposed to glomerular hyperfiltration and increased UAE, intensifying this process [91].

\section{Treatment}

The principles of prevention and treatment of DN are the same. However, the role of each factor could be different in each stage of disease. It is important to define the DN stage that is the target of intervention (microalbuminuria, proteinuria or GFR) and the outcome of interest. Two recent meta-analyses have demonstrated different results when evaluating different outcomes, such as proteinuria, GFR decline or progression to ESRD $[105,106]$. Both, ACE inhibitors and angiotensin receptor blockers (ARBs) seem to be effective reducing proteinuria and decreasing the creatinine doubling rate, but not decreasing mortality [106]. Probably the best treatment is a multiple risk factor interventional approach, but due to a practical point of view each aspect will be addressed individually. The goal to be pursued is retarding the development or progression of $\mathrm{DN}$ and to decrease the subject's cardiovascular risk and mortality.

In normo- or microalbuminuric subjects, the aim of treatment is to intervene at arterial hypertension, hyperglycemia, smoking habit and probably dyslipidemia. Even in the absence of clear data showing that the management of these risk factors individually is beneficial to DN, they are also risk factors for cardiovascular disease and should be aggressively treated [30].

Clinical trials have demonstrated that intensive treatment of hyperglycemia is associated with a decreased risk for the development of DN in type 1 and type 2 diabetic patients [107-110]. In type 1 and type 2 subjects the effect of intensive therapy could be seen many years later $[108,111]$. The effect of the intervention in hyperglycemia in type 1 macroalbuminuric subjects is not so clear $[107,112,113]$. This became more evident in the EDIC/ DCCT follow up study [108]. In the Kumamoto study, prevention of macroalbuminuria was observed in type 2 DM patients intensively treated [110].

Recent studies designed to evaluate the benefit of intensive glycemic control in large sets of patients showed a minor protective effect on the development of progression of albuminuria $[61,114]$. In the Intensive Blood Glucose Control and Vascular Outcomes in Patients with Type 2 Diabetes (ADVANCE) trial, the group in the intensive arm for an average of 5 years showed a small reduction in the number of cases with new-onset microalbuminuria compared to the standard therapy group (23.7 vs. $25.7 \%$ ) [61]. No effect was observed in the serum creatinine values [61]. The same was observed in the Glucose Control and Vascular Complications in Veterans with Type 2 Diabetes (VADT) study [114]. Patients in the intensive arm for a mean of 5.6 years did not show any benefit regarding changing serum creatinine or GFR val- 
ues [114] and a minor effect on albuminuria levels was observed [114].

Treatment of hypertension leads to an important risk reduction in cardiovascular and microvascular events. In the UKPDS, a reduction from 154 to $144 \mathrm{~mm} \mathrm{Hg}$ on systolic BP reduced the risk for the development of microalbuminuria by $29 \%$ [115]. BP targets for patients with DM are lower $(130 / 80 \mathrm{~mm} \mathrm{Hg})$ than those for patients without DM [116]. In the Hypertension Optimal Treatment (HOT) study a reduction of diastolic BP from 85 to 81 $\mathrm{mm} \mathrm{Hg}$ resulted in $50 \%$ reduction in the risk of cardiovascular events in diabetic but not in non-diabetic patients [117]. In the presence of microalbuminuria the treatment of hypertension, irrespective of the agent used, produced a beneficial effect on albuminuria [118].

Aggressive treatment of hypertension should be established in subjects with DM. A discussion of agents used to treat hypertension in patients with DN are beyond the scope of this manuscript, and recent guidelines $[108,116]$ and excellent reviews in this subject are available $[30,119,120]$.

In order to reach the BP goal of 130/80 $\mathrm{mmHg}$ in diabetic patients in general [116] or $125 / 75 \mathrm{mmHg}$ in patients with proteinuria $>1.0 \mathrm{~g} / 24 \mathrm{~h}$ and increased serum creatinine, three to four antihypertensive agents are usually necessary [121].

The choice of anti-hypertensive agents to use is in some way not a problem in clinical practice, because to reach the BP goals the majority of patients will need several agents. However, due to the known renoprotective effect of ACE inhibitors and ARB, these agents (see below) should be used initially associated with a diuretic.

\section{Renin-Angiotensin System (RAS) Blockade}

ACE inhibitors could be used in normotensive subjects to prevent or postpone the development of microalbuminuria [122]. The aim of ACE inhibitors and ARBs use is not only to diminish the risk for the development of microand macroalbuminuria [123-125] but also to decrease the occurrence of cardiovascular events [124]. However, a recent 5 year multicenter randomized controlled trial involving 285 normoalbuminuric, normotensive patients with type $1 \mathrm{DM}$ failed to show any improvement in biopsy parameters with losartan (100 mg daily) or enalapril (20 mg daily) compared to placebo [126]. Surprisingly, the 5-year cumulative incidence of microalbuminuria was $17 \%$ with losartan, significantly greater than with placebo $(6 \%, \mathrm{P}=0.01)$. The enalapril group had a similar incidence of microalbuminuria (4\%, $\mathrm{P}=0.96)$ in comparison to the placebo group [126].
RAS blockade with ACE inhibitors or ARB confers an additional benefit on renal function. This renoprotective effect is independent of BP reduction $[118,127]$. These drugs decrease UAE and the rate of progression from microalbuminuria to more advanced stages of DN. A meta-analysis of 12 trials in non-hypertensive microalbuminuric type 1 diabetic patients showed that ACE inhibitors decreased the risk of progression to macroalbuminuria by $60 \%$, and increased the chances of regression to normoalbuminuria [128]. Therefore, the use of ACE inhibitors or ARB is recommended for all microalbuminuric patients, even if normotensive [14]. ARBs were also effective in reducing the development of macroalbuminuria in microalbuminuric type 2 diabetic patients $[127,129]$.

The aggressive treatment of hypertension has a strong beneficial effect in reducing GFR decline in proteinuric type 1 diabetic patients [130]. This reduction in GFR decline was predicted by reduction in albuminuria [131]. According to the MDRD trial, the lower the BP the greater the preservation of renal function in non-diabetic patients [132]. Patients with proteinuria $>1 \mathrm{~g} /$ day and renal insufficiency had a slower decline in renal function when BP was $<125 / 75 \mathrm{~mm} \mathrm{Hg}$ [132]. Addition of ACE inhibitors in proteinuric type 1 [133] or ARB in macroalbuminuric type $2[134,135]$ diabetic patients has a beneficial effect in decreasing proteinuria and reducing renal function decline. The effect of ARBs on protein excretion could be noted within 7 days after starting the treatment, and may persist after [136]. It seems to be independent of BP reduction [127] and has a dose response effect beyond the doses needed to control BP [137]. An acute increase in serum creatinine up to 30 to $35 \%$ that stabilizes within 2 months might occur and it is not a reason to stop the treatment [138]. Increase in serum creatinine above these values should raise the possibility of renal-artery stenosis $[138,139]$. Another limitation to the use of ACE inhibitors is hyperkalemia, especially among those with renal insufficiency [138]. Acute hyperkalemia $(>5.5 \mathrm{mEqL})$ is an indication to stop these medications. Therefore, albuminuria, serum creatinine and potassium should be checked monthly in the first 2 to 3 months after starting treatment with ACE inhibitors or ARB $[138,139]$.

ACE inhibitors and ARB interrupt the RAS at different levels, and the combination of these classes of drugs (RAS dual blockade) has been proposed [140] as an alternative to treat DN. It has been suggested that this association would have an additive effect on renoprotection. The combination of ARB and ACE inhibitors are effective in reducing UAE ratio in hypertensive patients with type 2 DM when compared to each drug alone. However, this is also associated with lower BP values in the group that used both drugs $[140,141]$. A recent large trial (ONTARGET) in diabetic and nondiabetic subjects showed that 
the association of the two classes of drugs had a major effect on decreasing proteinuria but not on GFR decline or mortality [142]. In fact, a worse effect on GFR and mortality was observed. Analyzing the subgroups, the increased mortality came from the less sick subjects. Among diabetic subjects no increased mortality was observed, but also no benefit from the dual blockage was observed [142]. The VA NEPRHON-D study aimed to evaluate this issue is patients with type 2 DM [143].

Another step that has been proposed to be blocked is the aldosterone action. Adding the aldosterone antagonist spironolactone - to ARBs [144] or ACE inhibitor [145] is also more effective in reducing UAE and BP in type 2 diabetic patients than each drug alone. A recent meta-analyses that included diabetic and non-diabetic subjects demonstrated that the addition of aldosterone antagonists in patients already on ACE inhibitors and ARBs reduces proteinuria in chronic kidney disease [146]. This was not associated with an improvement on GFR, but increases the risk of hyperkalemia. Long-term effects of these agents on renal outcomes, mortality, and safety need to be determined [146].

More recently, the dual blockage of the renin-angiotensinaldosterone system with aliskiren, a direct renin inhibitor, and losartan at maximal recommended dose $(100 \mathrm{mg}$ daily) showed a greater reduction in proteinuria $(20 \%)$ compared to losartan and placebo [147]. The effect does not seem to be due to anti-hypertensive effect. However, this was a short duration study (12 weeks) and long term studies are needed. The ongoing trial ALTITUDE might answer some of these questions [148]. This placebo controlled, randomized trial intends to follow-up about 8600 subjects during two years and compare the effect of aliskiren added to standard treatment (ACE or ARBs) [148]. The results will be available by 2012 .

\section{Hyperglycemia treatment peculiarities}

The treatment of DM is not the aim of the present review, but a few special remarks could be made regarding the treatment of hyperglycemia in a patient with renal disease (Table 3).

Metformin is the standard therapy for patients with type 2 DM and will only be briefly discussed here. Metformin is contraindicated when serum creatinine is above $1.5 \mathrm{mg} / \mathrm{dl}$ in men and $1.4 \mathrm{mg} / \mathrm{dl}$ in women due to the increased risk of lactic acidosis [149]. However, these values are being questioned [150]. In these creatinine ranges, some subjects will be using metformin on chronic renal disease stages II and III [151].

Sulfonylureas and their metabolites, except glimepiride, are eliminated via renal excretion and should be used with caution in patients with GFR [152]. Glibenclamide is a potent drug and has been known for a long time. It is low cost and available in the public health system. However, it presents a high risk of hypoglycemia. It has active metabolites that increase in patients with decreased GFR, and its pharmacological action is such that the use of glibenclamide is not recommended from stage 3 onwards $[153,154]$. Among the sulfonylureas there is also glipizide which carries a lower risk of hypoglycemia being and alternative on this situation [154]. Glipizide can be used in chronic renal disease stages 3 and 4 . It could still be used in stage 5, with a therapeutic adjustment. Glimepiride is a third generation sulfonylurea with a slightly higher cost and a lower risk of hypoglycemia. However, it is believed that it has a few active metabolites filtered by the kidneys what could be potentially related to higher risk of hypoglycemia compared to glipizide.

Repaglinide [155] and nateglinide [156] have a short duration of action, are excreted independently of renal function and have a safety profile in patients with renal impairment. These drugs, like the sulfonylureas, are insulin secretagogues, but they act in different cellular membrane channels, and this brings some pharmacological properties such as quick initial action, non-prolonged action and greater effect on post-prandial glycemia. A flexible aspect of this drugs making therapeutic management easier is the lower risk of hypoglycemia because of the different connection of the membrane channels. But one side effect described similar to observed with the sulfonylureas is weight gain. Its cost is higher than that of sulfonylureas, but theoretically it has a less deleterious effect on beta cells. Among the glinides, the first choice would be repaglinide because of the low risk of hypoglycemia, and it can be used in stage 3 and stage $4[155,157]$. Data in the literature are not sufficient to indicate the use of this drug in chronic renal disease stage 5. Nateglinide would be at a disadvantage because it is less potent, and it has active metabolites that can increase the risk of hypoglycemia in subjects with decreased GFR $[158,159]$.

Acarbose is a drug that is not potent to reduce HbA1c. However, as its pharmacological action principle is the inhibition of enzyme alpha glycosidase in the small bowel, reducing glucose absorption in the gastrointestinal tract, it is a useful drug to adjust post-prandial hyperglycemia. The metabolism of this drug is practically $100 \%$ gastrointestinal, part is excreted in the urine and most of it in the feces, and a small form is excreted in the form of the active metabolite $[153,160]$. The concern of using acarbose in subjects with chronic kidney disease is the accumulation of these metabolites that may lead to hepatic lesions. Thus, acarbose would be contraindicated in subjects with chronic renal disease. There are insufficient data in the literature to use this drug with a creatinine greater 
Table 3: Treatment of hyperglycemia in the patient with type 2 diabetes mellitus and chronic kidney disease

\begin{tabular}{|c|c|c|c|c|c|c|}
\hline & \multirow[b]{2}{*}{ Clearance } & \multirow[b]{2}{*}{$\begin{array}{c}\text { Reduction of } \\
\text { HbAlc }\end{array}$} & \multirow[b]{2}{*}{$\begin{array}{c}\text { Risk of } \\
\text { hypoglycemia }\end{array}$} & \multicolumn{3}{|c|}{ Stage of Renal Disease } \\
\hline & & & & III & IV & $\mathbf{V}$ \\
\hline $\begin{array}{l}\text { Glibenclamide } \\
{[153,154]}\end{array}$ & $\begin{array}{l}\text { Hepatic metabolism: } \\
100 \% \text {. } \\
\text { Excretion: bile and } \\
\text { feces } 50 \% \text { and urine } \\
50 \%\end{array}$ & $-1.5 \%$ & $\begin{array}{c}\text { High } \\
\text { (active metabolites) }\end{array}$ & Avoid & Avoid & Avoid \\
\hline Glipizide [154] & $\begin{array}{l}\text { Excretion: } \\
\text { metabolites } 90 \% \text { in } \\
\text { urine and feces. } 10 \% \\
\text { excreted without } \\
\text { metabolization }\end{array}$ & $-1.5 \%$ & Low & Can be used & Can be used & $\begin{array}{l}\text { Can be used } \\
\text { (adjustments) }\end{array}$ \\
\hline Glimepyride & $\begin{array}{l}\text { Hepatic metabolism } \\
100 \% \text {. } \\
\text { Excretion: urine } \\
60 \% \text { and feces } 40 \%\end{array}$ & $-1.5 \%$ & Low & Can be used & Can be used & Use with care \\
\hline $\begin{array}{l}\text { Repaglinide } \\
{[155,157]}\end{array}$ & $\begin{array}{l}\text { Hepatic metabolism: } \\
100 \% \text {. } \\
\text { Excretion: } 10 \% \\
\text { urine and } 90 \% \text { feces }\end{array}$ & $-1.0 \%$ & Low & Can be used & Can be used & $\begin{array}{l}\text { Use with care. } \\
\text { Adjust dose }\end{array}$ \\
\hline $\begin{array}{l}\text { Nateglinide } \\
{[156,158,159]}\end{array}$ & $\begin{array}{l}\text { Hepatic metabolism: } \\
85 \% \text {. } \\
\text { Excretion: urine } \\
83 \% \text { and feces } 10 \% \text {. } \\
15 \% \text { excreted } \\
\text { inactive in urine }\end{array}$ & $-0.7 \%$ & $\begin{array}{c}\text { High } \\
\text { (active metabolites) }\end{array}$ & Use with care & Use with care & Avoid if possible \\
\hline $\begin{array}{l}\text { Acarbose* } \\
{[153,160]}\end{array}$ & $\begin{array}{l}\text { Excretion: urine } \\
34 \% \text {, feces } 51 \% \text { and } \\
<2 \% \text { in urine in the } \\
\text { free or active } \\
\text { metabolic form }\end{array}$ & $-0.6 \%$ & Low & Can be used & Can be used & Avoid \\
\hline Rosiglitazone [162] & $\begin{array}{l}\text { Hepatic metabolism } \\
\text { and excretion in the } \\
\text { urine, of rather } \\
\text { inactive metabolites } \\
\text { in the urine } 64 \% \text { and } \\
\text { feces } 23 \%\end{array}$ & -0.6 to $1.5 \%$ & Low & Can be used & Can be used & Can be used \\
\hline Pioglitazone [162] & $\begin{array}{l}\text { Hepatic metabolism } \\
\text { and excretion in } \\
\text { urine of rather } \\
\text { inactive metabolites } \\
\text { in the urine } 15 \% \text { and } \\
\text { feces } 85 \%\end{array}$ & -0.6 to $1.5 \%$ & Low & Can be used & Can be used & Can be used \\
\hline $\begin{array}{l}\text { Sitaglipitine } \\
{[171,172]}\end{array}$ & $\begin{array}{l}\text { Excretion: urine } \\
87 \% \text { and feces } 13 \% \text {, } \\
\text { in an unaltered } \\
\text { form. }\end{array}$ & $-0.7 \%$ & Low & Can be used & $\begin{array}{c}\text { Can be used. } \\
\text { Reduce dose } 50 \%\end{array}$ & $\begin{array}{c}\text { Can be used. } \\
\text { Reduce dose } 75 \%\end{array}$ \\
\hline Vildagliptine & $\begin{array}{l}\text { Excretion: urine: } \\
85 \% \text { and feces } 15 \% \text {. }\end{array}$ & $-0.7 \%$ & Low & Can be used & Can be used & Not recommended \\
\hline Exanetide [173] & $\begin{array}{l}\text { Metabolism and } \\
\text { renal excretion }\end{array}$ & $-1.0 \% * *$ & Low & Can be used & Not recommended & Not recommended \\
\hline
\end{tabular}


than $2 \mathrm{mg} / \mathrm{dl}$. It could be considered up to stage 3 , and it should be avoided in stages 4 and $5[153,160]$.

Glitazones, represented by rosiglitazone and pioglitazone, act through the PPR gamma system and are insulin sensitizer drugs that increase the muscle uptake of glucose and diminish the atherogenic profile of the DM patient, and could be used in renal failure [161,162]. Rosiglitazone has been shown to decrease UAE in type 2 diabetic patients as compared to glyburide, suggesting a beneficial effect in the prevention of renal complications of type 2 DM [163]. This antiproteinuric effect occurs also in nondiabetic disease $[161,164,165]$. The side effects include anemia, water retention, weight gain and potential hepatotoxicity due to the accumulation of its metabolites. Recently, cardiovascular safety and the risk of increased incidence of fractures have been discussed $[166,167]$. Both would present a low risk of hypoglycemia and could theoretically be used in the different stages of chronic renal disease without adjusting the dose [168].

A recent meta-analysis suggests beneficial effects of glitazones, with improvement of dyslipidemia in DM, internal carotid intima layer thickness reduction, improved fibrinolysis, and a direct action of the PPR gamma system at glomerular, tubular and vascular levels [169]. In theory, all these actions (hemodynamic, anti-inflammatory, antiproliferative and metabolic) would be beneficial actions in nephropathy [169].

In relation to fractures, a recent meta-analysis showed that in the female population there has been up to two-fold increase in the incidence of fractures including both hip and vertebral fractures [170]. Since a uremic patient has already an increased osteometabolic risk, a drug that would increase the incidence of fractures should be questioned in these patients.

Two representatives of the DPP-4 inhibitors are available, vildagliptin and sitagliptin. These drugs inhibit the dipeptidyl peptidase- 4 enzyme which, in turn, prevents degradation of the GLP-1 which remains active longer. Thus they lead to the reduction of fasting and post-prandial glycemia, without a risk of hypoglycemia. The gliptins suppress the high release of glucagon and are neutral as regards weight. The side effects include airway infection and transaminases elevation. The standard dose is 100 $\mathrm{mg}$, orally, in a single daily dose. Sitagliptin secretion occurs mostly in urine and an adjustment in the dose is recommended according to the stage of renal disease: 50 $\mathrm{mg}$ for stage 3 and $25 \mathrm{mg}$ for stages 4 and 5 [171,172]. Vildagliptin also is predominantly excreted in the urine. It is unnecessary to adjust the dose in patients with mild or moderate renal failure (50 mg orally, bid). The use of vildagliptin is not recommended, according to the directions that accompany medications, in patients with severe renal failure, patients who are already on dialysis or some other renal substitution therapy.

Exenatide is a GLP-1 analog. Subcutaneous applications (beginning at $5 \mu \mathrm{g}$ bid for 30 days and then $10 \mu \mathrm{g}$ bid) should be performed up to one hour before meals twice a day. It is a drug that reduces weight, which may be an advantage in managing the diabetic patient. The major side effects are nausea and vomiting, what occasionally an individual cannot tolerate using it. It is metabolized and excreted by the kidneys. It presents a low risk of hypoglycemia and can be used in stage 3, and it is not recommended in stages 4 and 5 due to the increased risk of side effects [173].

However, when the renal function is highly compromised, metformin, exenatide and gliptins are contraindicated, and insulin secretagogues are usually not very effective, since these patients have low endogenous production of insulin. Therefore, most patients should be treated with insulin [153]. We should remember that the half life of insulin is changed as soon as the individual begins to have a major renal function impairment. Pharmacokinetics is modified, and the insulin will have a slightly longer profile. This may make it difficult to manage the day to day situation, in peculiar situations on different days, i.e., the individual who is undergoing a dialysis session may feel bad and change his diet on that day. We should be able to rationalize more with the flexibility of doses here, which is often rather difficult for the patient and the physician.

These individuals certainly will have a greater propensity to hypoglycemia, so we have to be more careful and remember that hypoglycemia may be one of the complications implicated in the increased cardiovascular mortality of these patients. We should also keep in mind that therapeutic goals should be individualized.

\section{Dietary intervention}

There are several modalities for a dietary intervention in $\mathrm{DN}$, whether changing protein content or through the manipulation of lipid content. However, few have their efficacy shown based on long term randomized clinical trials.

In patients with type $1 \mathrm{DM}$, in different stages of renal disease, protein restriction in the diet has shown that it can reduce the decline of renal function and albuminuria. According to a meta-analysis of studies performed with type 1 DM patients and clinical nephropathy, dietary protein restriction retards DN progression [174]. However, several of these studies were randomized with a crossover design, and the maximum time of follow up was 36 
months. Besides, in these studies there was no evidence of benefit on hard outcomes such as mortality or risk of end stage chronic renal failure. A randomized controlled clinical trial with patients with type $1 \mathrm{DM}$ and DN followed for four years, showed that a diet with a moderate protein restriction $(0.9 \mathrm{~g} / \mathrm{kg} / \mathrm{day})$ was associated with a $76 \%$ reduction of the risk of end stage chronic renal failure or death [175].

In patients with type 2 DM this benefit has not been well established. There are few studies with type 2 DM patients addressing this issue, showing no benefit on renal function, probably due to lack of compliance with the diet and short follow-up [176]. A recent meta-analysis performed with eight studies including patients with type 1 and 2 DM showed a benefit of protein restriction on proteinuria reduction, but not on GFR reduction [177]. The American Diabetes Association recommends moderate protein restriction $(0.8-1.0 \mathrm{~g} / \mathrm{kg} / \mathrm{day})$ for patients in the initial stages of DN, and a reduction to $0.8 \mathrm{~g} / \mathrm{kg} /$ day for patients in a more advanced stage of this complication [27].

Interventions in the dietary lipid content has also been suggested, especially by manipulating the type of meat in the diet. Substituting red meat by chicken meat in the diet over the short term proved be able to reduce UAE, and also the serum levels of total cholesterol, LDL and apolipoprotein $\mathrm{B}$ in patients with type $2 \mathrm{DM}$ and micro and macroalbuminuria [89,178]. Recently it was also observed that the beneficial effect of this dietary intervention on renal function was similar to the use of enalapril for a 12-month period in patients with type 2 DM [179]. This effect is probably related to the lower saturated fat content and greater proportion of polyunsaturated fatty acids, observed in chicken meat compared to red meat. Long term studies are needed to confirm this favorable effect.

\section{Dyslipidemia}

The desired target of LDL is $<100 \mathrm{mg} / \mathrm{dl}$ for patients with DM in general, and $<70 \mathrm{mg} / \mathrm{dl}$ when cardiovascular disease is present. No data based on a large clinical trial is available showing that the treatment of dyslipidemia is able to prevent the development or progression of DN. In the Heart Protection Study (HPS), sinvastatin, $40 \mathrm{mg}$, reduced vascular event rates and GFR decline in patients with DM by $25 \%$, independent of baseline cholesterol levels. Furthermore the results of the Collaborative Atorvastatin Diabetes Study (CARDS) demonstrated a marked reduction in cardiovascular events in DM patients, and at least one additional risk factor for coronary disease, suggesting that all DM patients should use statins. A recent publication of CARDS showed a modest beneficial effect of atorvastatin on eGFR, particularly in those with albu- minuria [180]. However, atorvastatin did not influence albuminuria incidence [180].

\section{Multifactorial intervention}

As stated before, probably the best approach to a subject with $\mathrm{DN}$ is a multifactorial intervention. However, only one study, with a small number of patients $(\mathrm{n}=160)$ addressed this aspect [181]. In this study the targets were: BP levels $<130 / 80 \mathrm{~mm} \mathrm{Hg}$, fasting serum cholesterol $<175$ $\mathrm{mg} / \mathrm{dl}$, fasting serum triglycerides $<150 \mathrm{mg} / \mathrm{dl}$, and $\mathrm{HbA} 1_{c}$ $<6.5 \%$. The intervention consisted of a stepwise implementation of lifestyle changes and pharmacological therapy including low-fat diet, three to five times a week lightto-moderate exercise program, smoking-cessation course, and prescription of ACE inhibitors or ARB and aspirin. The multiple intervention group had a $61 \%$ reduction in the risk of macroalbuminuria, and a $58 \%$ and $63 \%$ reduction in the risk of retinopathy and autonomic neuropathy, respectively. Most importantly, a 55\% reduction in the risk for the development of a composite end-point consisting of death from cardiovascular causes, non-fatal myocardial infarction, revascularization procedures, nonfatal stroke and amputation was also associated with the multifactorial intervention. It is important to point out that even among highly motivated subjects only a small number reached the proposed goals. Less than $20 \%$ in the intensive arm reached the HbA1c goal and less than $50 \%$ the systolic BP goal [181].

\section{Conclusion}

Diabetic nephropathy is a chronic complication of DM with a growing incidence. Therefore it is essential to have a better understanding of it, especially in relation to prevention and aggressive management to avoid progression to ESRD. Besides, its direct association with cardiovascular complications makes it imperative to perform intensive, early management of the risk factors. The study of DN has evolved a lot as regards its pathophysiology, stages of renal involvement and, especially, the therapeutic instruments available. Early detection of DN, the multifactorial approach targeting the main risk factors (hyperglycemia, hypertension, dyslipidemia and smoking), and the use of renoprotective agents such as the drugs that act on the renin-angiotensin-aldosterone system, may delay progression of kidney disease in DM, besides reducing cardiovascular mortality.

\section{Abbreviations}

ACE: angiotensin convertin enzyme; ARB: angiotensin receptor blocker; $\mathrm{BP}$ : blood pressure; $\mathrm{DM}$ : diabetes mellitus; DN: diabetic neprhopathy; ESRD: end-stage renal disease; ET-1: endothelin-1; GFR: glomerular filtration rate; HbA1c: glicohemoglobin A1c; MDRD: Modification of Diet in Renal Disease; RAS: renin-angiotensin system; UAE: urinary albumin excretion. 


\section{Competing interests}

The authors declare that they have no competing interests.

\section{Authors' contributions}

All authors contributed in the same way.

\section{Acknowledgements}

This study was partially supported by Projeto de Núcleos de Excelência do Ministério de Ciência e Tecnologia, Conselho Nacional de Desenvolvimento Científico e Tecnológico (CNPq) and Fundo de Incentivo a Pesquisa e Eventos (FIPE) do Hospital de Clínicas de Porto Alegre.

\section{References}

I. U.S. Renal Data System, USRDS 2003 Annual Data Report: Atlas of End-Stage Renal Disease in the United States, National Institute of Health, National Institute of Diabetes and Digestive and Kidney Diseases, Bethesda, MD, 2003.

2. Bruno RM, Gross JL: Prognostic factors in Brazilian diabetic patients starting dialysis: a 3.6-year follow-up study. J Diabetes Complications 2000, 14:266-27I.

3. Valmadrid CT, Klein R, Moss SE, Klein BE: The risk of cardiovascular disease mortality associated with microalbuminuria and gross proteinuria in persons with older-onset diabetes mellitus. Arch Intern Med 2000, 160:1093-1100.

4. Mogensen CE, Christensen CK: Predicting diabetic nephropathy in insulin-dependent patients. N Engl J Med I984, 3 I I:89-93.

5. Parving HH, Oxenboll B, Svendsen PA, Christiansen JS, Andersen AR: Early detection of patients at risk of developing diabetic nephropathy. A longitudinal study of urinary albumin excretion. Acta Endocrinol (Copenh) 1982, 100:550-555.

6. Viberti GC, Hill RD, Jarrett RJ, Argyropoulos A, Mahmud U, Keen H Microalbuminuria as a predictor of clinical nephropathy in insulin- dependent diabetes mellitus. Lancet I982, I: | 430- | 432.

7. Mogensen CE: Microalbuminuria predicts clinical proteinuria and early mortality in maturity-onset diabetes. $N$ Engl J Med 1984, 3 10:356-360.

8. Maclsaac RJ, Tsalamandris C, Panagiotopoulos S, Smith TJ, McNeil KJ Jerums G: Nonalbuminuric renal insufficiency in type 2 diabetes. Diabetes Care 2004, 27: 195-200.

9. Caramori ML, Fioretto P, Mauer M: Low glomerular filtration rate in normoalbuminuric type I diabetic patients: an indicator of more advanced glomerular lesions. Diabetes 2003 52:1036-1040.

10. Kramer CK, Leitao CB, Pinto LC, Silveiro SP, Gross JL, Canani LH: Clinical and laboratory profile of patients with type 2 diabetes with low glomerular filtration rate and normoalbuminuria. Diabetes Care 2007, 30:1998-2000.

II. Perkins BA, Krolewski AS: Early nephropathy in type I diabetes: the importance of early renal function decline. Curr Opin Nephrol Hypertens 2009, 18:233-240.

12. Young BA, Maynard C, Boyko E): Racial differences in diabetic nephropathy, cardiovascular disease, and mortality in a national population of veterans. Diabetes Care 2003, 26:2392-2399.

13. Gerchman F, Zanatta CM, Burttet LM, Picon PX, Lisboa HR, Silveiro SP, Gross JL, Canani LH: Vascular complications of black patients with type 2 diabetes mellitus in Southern Brazil. Braz J Med Biol Res 2008, 41:668-673.

14. American Diabetes Association: Nephropathy in Diabetes. Diabetes Care 2004, 27:S79-83.

15. Caramori ML, Fioretto $P$, Mauer $M$ : The need for early predictors of diabetic nephropathy risk: is albumin excretion rate sufficient? Diabetes 2000, 49:1399-1408.

16. Perkins BA, Ficociello LH, Silva KH, Finkelstein DM, Warram JH, Krolewski AS: Regression of microalbuminuria in type I diabetes. N Engl J Med 2003, 348:2285-2293.

17. Dinneen SF, Gerstein HC: The association of microalbuminuria and mortality in non-insulin-dependent diabetes mellitus. A systematic overview of the literature. Arch Intern Med 1997, I57:1413-1418.

18. Stehouwer CD, Gall MA, Twisk JW, Knudsen E, Emeis J], Parving HH: Increased urinary albumin excretion, endothelial dysfunc- tion, and chronic low-grade inflammation in type 2 diabetes: progressive, interrelated, and independently associated with risk of death. Diabetes 2002, 5 I: I I57-1 I65.

19. Forsblom CM, Groop PH, Ekstrand A, Totterman KJ, Sane T, Saloranta C, Groop L: Predictors of progression from normoalbuminuria to microalbuminuria in NIDDM. Diabetes Care 1998, 21:1932-1938.

20. Murussi M, Baglio P, Gross JL, Silveiro SP: Risk factors for microalbuminuria and macroalbuminuria in type 2 diabetic patients: a 9-year follow-up study. Diabetes Care 2002, 25:IIOI-II03.

21. Predictors of the development of microalbuminuria in patients with Type I diabetes mellitus: a seven-year prospective study. The Microalbuminuria Collaborative Study Group. Diabet Med 1999, 16:918-925.

22. Leitao CB, Canani LH, Polson PB, Molon MP, Pinotti AF, Gross JL: Urinary albumin excretion rate is associated with increased ambulatory blood pressure in normoalbuminuric type $\mathbf{2}$ diabetic patients. Diabetes Care 2005, 28: 1724-1729.

23. Viberti GC, Bilous RW, Mackintosh D, Keen H: Monitoring glomerular function in diabetic nephropathy. A prospective study. Am J Med 1983, 74:256-264.

24. Gall MA, Nielsen FS, Smidt UM, Parving HH: The course of kidney function in type 2 (non-insulin-dependent) diabetic patients with diabetic nephropathy. Diabetologia 1993, 36:107|-1078.

25. Friedman R, Gross JL: Evolution of glomerular filtration rate in proteinuric NIDDM patients. Diabetes Care 199I, 14:355-359.

26. Nosadini R, Velussi M, Brocco E, Bruseghin M, Abaterusso C, Saller A, Dalla Vestra M, Carraro A, Bortoloso E, Sambataro M, Barzon I, Frigato F, Muollo B, Chiesura-Corona M, Pacini G, Baggio B, Piarulli F, Sfriso $A$, Fioretto $P$ : Course of renal function in type 2 diabetic patients with abnormalities of albumin excretion rate. Diabetes 2000, 49:476-484.

27. Standards of medical care in diabetes--2009. Diabetes Care 2009, 32(SuppI I):SI3-6I.

28. Zelmanovitz T, Gross JL, Oliveira JR, Paggi A, Tatsch M, Azevedo MJ: The receiver operating characteristics curve in the evaluation of a random urine specimen as a screening test for diabetic nephropathy. Diabetes Care 1997, 20:516-5I9.

29. Incerti J, Zelmanovitz T, Camargo JL, Gross JL, de Azevedo MJ: Evaluation of tests for microalbuminuria screening in patients with diabetes. Nephrol Dial Transplant 2005, 20:2402-2407.

30. Gross JL, de Azevedo MJ, Silveiro SP, Canani LH, Caramori ML, Zelmanovitz T: Diabetic nephropathy: diagnosis, prevention, and treatment. Diabetes Care 2005, 28:164- 176.

3I. Mogensen CE, Vestbo E, Poulsen PL, Christiansen C, Damsgaard EM, Eiskjaer H, Froland A, Hansen KW, Nielsen S, Pedersen MM: Microalbuminuria and potential confounders. $A$ review and some observations on variability of urinary albumin excretion. Diabetes Care 1995, 18:572-581.

32. Levey AS, Eckardt KU, Tsukamoto Y, Levin A, Coresh J, Rossert J, De Zeeuw D, Hostetter TH, Lameire N, Eknoyan G: Definition and classification of chronic kidney disease: a position statement from Kidney Disease: Improving Global Outcomes (KDIGO). Kidney Int 2005, 67:2089-2100.

33. Beetham R, Cattell WR: Proteinuria: pathophysiology, significance and recommendations for measurement in clinical practice. Ann Clin Biochem 1993, 30(Pt 5):425-434.

34. Kramer CK, Camargo J, Ricardo ED, Almeida FK, Canani LH, Gross JL, Azevedo MJ: Does bacteriuria interfere with albuminuria measurements of patients with diabetes? Nephrol Dial Transplant 2009, 24: I 193-1 I 96.

35. Comper WD, Osicka TM, Jerums G: High prevalence of immuno-unreactive intact albumin in urine of diabetic patients. Am J Kidney Dis 2003, $41: 336-342$.

36. Brinkman JW, Bakker SJ, Gansevoort RT, Hillege HL, Kema IP, Gans $R O$, de Jong $P E$, de Zeeuw $D$ : Which method for quantifying urinary albumin excretion gives what outcome? A comparison of immunonephelometry with HPLC. Kidney Int Suppl 2004:S69-75.

37. Comper WD, Osicka TM, Clark M, Maclsaac RJ, Jerums G: Earlier detection of microalbuminuria in diabetic patients using a new urinary albumin assay. Kidney Int 2004, 65:1850-I855.

38. Comper WD, Osicka TM: Detection of urinary albumin. Adv Chronic Kidney Dis 2005, I 2: I 70-176. 
39. Jerums G, Premaratne E, Panagiotopoulos S, Clarke S, Power DA, Maclsaac RJ: New and old markers of progression of diabetic nephropathy. Diabetes Res Clin Pract 2008, 82(Suppl I):S30-37.

40. Levey AS, Coresh J, Balk E, Kausz AT, Levin A, Steffes MW, Hogg RJ, Perrone RD, Lau J, Eknoyan G: National Kidney Foundation practice guidelines for chronic kidney disease: evaluation, classification, and stratification. Ann Intern Med 2003, 139:137-147.

4I. Granerus G, Aurell M: Reference values for 5 I Cr-EDTA clearance as a measure of glomerular filtration rate. Scand J Clin Lab Invest 198I, 41:6II-616.

42. Christensen PK, Larsen S, Horn T, Olsen S, Parving HH: Renal function and structure in albuminuric type 2 diabetic patients without retinopathy. Nephrol Dial Transplant 200 I, 16:2337-2347.

43. Mauer M, Fioretto P, Woredekal Y, Friedman EA: Diabetic Nephropathy. In Diseases of the Kidney and Urinary Tract 7th edition. Edited by: Schrier RW. Lippincott Williams \& Wilkins; 200I:2083-2II6.

44. Huang F, Yang Q, Chen L, Tang S, Liu W, Yu X: Renal pathological change in patients with type 2 diabetes is not always diabetic nephropathy: a report of $\mathbf{5 2}$ cases. Clin Nephrol 2007, 67:293-297.

45. Wong TY, Choi PC, Szeto CC, To KF, Tang NL, Chan AW, Li PK, Lai FM: Renal outcome in type 2 diabetic patients with or without coexisting nondiabetic nephropathies. Diabetes Care 2002, 25:900-905.

46. Krolewski AS, Warram JH, Christlieb AR, Busick EJ, Kahn CR: The changing natural history of nephropathy in type I diabetes. Am J Med I 985, 78:785-794.

47. Krolewski AS: Genetics of diabetic nephropathy: evidence for major and minor gene effects. Kidney Int 1999, 55:1582-1596.

48. Krolewski AS, Ng DP, Canani LH, Warram JH: Genetics of diabetic nephropathy: how far are we from finding susceptibility genes? Adv Nephrol Necker Hosp 200I, 3 I:295-3I5.

49. Quinn M, Angelico MC, Warram JH, Krolewski AS: Familial factors determine the development of diabetic nephropathy in patients with IDDM. Diabetologia 1996, 39:940-945.

50. Pettitt DJ, Saad MF, Bennett PH, Nelson RG, Knowler WC: Familia predisposition to renal disease in two generations of Pima Indians with type 2 (non-insulin-dependent) diabetes mellitus. Diabetologia 1990, 33:438-443.

5I. Freedman BI, Tuttle AB, Spray BJ: Familial predisposition to nephropathy in African-Americans with non-insulin-dependent diabetes mellitus. Am J Kidney Dis 1995, 25:710-7I3.

52. Clustering of long-term complications in families with diabetes in the diabetes control and complications trial. The Diabetes Control and Complications Trial Research Group. Diabetes 1997, 46:1829-1839.

53. Canani LH, Gerchman F, Gross JL: Familial clustering of diabetic nephropathy in Brazilian type 2 diabetic patients. Diabetes 1999, 48:909-913.

54. Placha G, Canani LH, Warram JH, Krolewski AS: Evidence for different susceptibility genes for proteinuria and ESRD in type 2 diabetes. Adv Chronic Kidney Dis 2005, I 2:155-169.

55. Gall MA, Hougaard P, Borch-Johnsen K, Parving HH: Risk factors for development of incipient and overt diabetic nephropathy in patients with non-insulin dependent diabetes mellitus: prospective, observational study. BMJ 1997, 3 | 4:783-788.

56. Ravid M, Brosh D, Ravid-Safran D, Levy Z, Rachmani R: Main risk factors for nephropathy in type 2 diabetes mellitus are plasma cholesterol levels, mean blood pressure, and hyperglycemia. Arch Intern Med 1998, I 58:998-1004.

57. Stratton IM, Adler AI, Neil HA, Matthews DR, Manley SE, Cull CA Hadden D, Turner RC, Holman RR: Association of glycaemia with macrovascular and microvascular complications of type 2 diabetes (UKPDS 35): prospective observational study. BMJ 2000, 32 I:405-4I2.

58. Alaveras AE, Thomas SM, Sagriotis A Viberti GC: Promoters of progression of diabetic nephropathy: the relative roles of blood glucose and blood pressure control. Nephrol Dial Transplant 1997, I 2(Suppl 2):7I-74.

59. Hovind P, Rossing P, Tarnow L, Parving HH: Smoking and progression of diabetic nephropathy in type I diabetes. Diabetes Care 2003, 26:911-916.

60. Fioretto P, Steffes MW, Sutherland DE, Goetz FC, Mauer M: Reversal of lesions of diabetic nephropathy after pancreas transplantation. $N$ Engl J Med 1998, 339:69-75.
61. Patel A, MacMahon S, Chalmers J, Neal B, Billot L, Woodward M, Marre M, Cooper M, Glasziou P, Grobbee D, Hamet P, Harrap S, Heller S, Liu L, Mancia G, Mogensen CE, Pan C, Poulter N, Rodgers A, Williams B, Bompoint S, de Galan BE, Joshi R, Travert F: Intensive blood glucose control and vascular outcomes in patients with type 2 diabetes. N Engl J Med 2008, 358:2560-2572.

62. Park JY, Kim HK, Chung YE, Kim SW, Hong SK, Lee KU: Incidence and determinants of microalbuminuria in Koreans with type 2 diabetes. Diabetes Care 1998, 21:530-534.

63. Adler AI, Stratton IM, Neil HA, Yudkin JS, Matthews DR, Cull CA, Wright AD, Turner RC, Holman RR: Association of systolic blood pressure with macrovascular and microvascular complications of type 2 diabetes (UKPDS 36): prospective observational study. BMJ 2000, 321:4I2-4I9.

64. Sawicki PT, Didjurgeit U, Muhlhauser I, Bender R, Heinemann L, Berger M: Smoking is associated with progression of diabetic nephropathy. Diabetes Care 1994, 17:|26-|3|.

65. Smulders YM, Rakic M, Stehouwer CD, Weijers RN, Slaats EH, Silberbusch J: Determinants of progression of microalbuminuria in patients with NIDDM. A prospective study. Diabetes Care 1997, 20:999-1005.

66. Chaturvedi N, Fuller JH, Taskinen MR: Differing associations of lipid and lipoprotein disturbances with the macrovascular and microvascular complications of type I diabetes. Diabetes Care 200I, 24:207I-2077.

67. Jenkins AJ, Lyons TJ, Zheng D, Otvos JD, Lackland DT, McGee D, Garvey WT, Klein RL: Lipoproteins in the DCCT/EDIC cohort: associations with diabetic nephropathy. Kidney Int 2003, 64:817-828

68. Mulec H, Johnsen SA, Wiklund O, Bjorck S: Cholesterol: a renal risk factor in diabetic nephropathy? Am J Kidney Dis 1993 , 22:|96-20|

69. Ruggenenti P, Remuzzi G: Nephropathy of type-2 diabetes mellitus. J Am Soc Nephrol 1998, 9:2157-2169.

70. Remuzzi G, Ruggenenti P, Benigni A: Understanding the nature of renal disease progression. Kidney Int 1997, 51:2-15.

7I. Caramori ML, Gross JL, Pecis M, de Azevedo MJ: Glomerular filtration rate, urinary albumin excretion rate, and blood pressure changes in normoalbuminuric normotensive type I diabetic patients: an 8-year follow-up study. Diabetes Care 1999, 22:1512-1516.

72. Silveiro SP, Friedman R, Gross JL: Glomerular hyperfiltration in NIDDM patients without overt proteinuria. Diabetes Care 1993, 16:115-119.

73. Brenner BM, Lawler EV, Mackenzie HS: The hyperfiltration theory: a paradigm shift in nephrology. Kidney lnt 1996, 49: $1774-1777$.

74. Dahlquist G, Stattin EL, Rudberg S: Urinary albumin excretion rate and glomerular filtration rate in the prediction of diabetic nephropathy; a long-term follow-up study of childhood onset type-I diabetic patients. Nephrol Dial Transplant 200I, 16:1382-1386.

75. Silveiro SP, da Costa LA, Beck MO, Gross JL: Urinary albumin excretion rate and glomerular filtration rate in single-kidney type 2 diabetic patients. Diabetes Care 1998, 21:1521-1524.

76. Ficociello LH, Perkins BA, Roshan B, Weinberg JM, Aschengrau A Warram JH, Krolewski AS: Renal hyperfiltration and the development of microalbuminuria in type I diabetes. Diabetes Care 2009, 32:889-893.

77. Chang S, Caramori ML, Moriya R, Mauer M: Having one kidney does not accelerate the rate of development of diabetic nephropathy lesions in type I diabetic patients. Diabetes 2008, 57: $1707-1711$.

78. Yip JW, Jones SL, Wiseman MJ, Hill C, Viberti G: Glomerular hyperfiltration in the prediction of nephropathy in IDDM: a 10-year follow-up study. Diabetes 1996, 45: I729-1733.

79. Toeller M, Buyken A, Heitkamp G, Bramswig S, Mann J, Milne R, Gries $\mathrm{FA}$, Keen $\mathrm{H}$ : Protein intake and urinary albumin excretion rates in the EURODIAB IDDM Complications Study. Diabetologia 1997, 40:1219-1226.

80. Mollsten AV, Dahlquist GG, Stattin EL, Rudberg S: Higher intakes of fish protein are related to a lower risk of microalbuminuria in young Swedish type I diabetic patients. Diabetes Care 200I, 24:805-8I0. 
81. Pecis M, de Azevedo MJ, Gross JL: Chicken and fish diet reduces glomerular hyperfiltration in IDDM patients. Diabetes Care 1994, I 7:665-672.

82. Riley MD, Dwyer T: Microalbuminuria is positively associated with usual dietary saturated fat intake and negatively associated with usual dietary protein intake in people with insulindependent diabetes mellitus. Am J Clin Nutr 1998, 67:50-57.

83. Almeida JC, Zelmanovitz T, Vaz JS, Steemburgo T, Perassolo MS, Gross JL, Azevedo MJ: Sources of protein and polyunsaturated fatty acids of the diet and microalbuminuria in type 2 diabetes mellitus. J Am Coll Nutr 2008, 27:528-537.

84. Cardenas C, Bordiu E, Bagazgoitia J, Calle-Pascual AL: Polyunsaturated fatty acid consumption may play a role in the onset and regression of microalbuminuria in well-controlled type $I$ and type 2 diabetic people: a 7-year, prospective, populationbased, observational multicenter study. Diabetes Care 2004, 27:|454-1457.

85. Seaquist ER, Goetz FC, Rich S, Barbosa J: Familial clustering of diabetic kidney disease. Evidence for genetic susceptibility to diabetic nephropathy. N Engl ] Med I989, 320: I |6 I-I I65.

86. Krolewski AS, Poznik GD, Placha G, Canani L, Dunn J, Walker W, Smiles A, Krolewski B, Fogarty DG, Moczulski D, Araki S, Makita Y, $\mathrm{Ng}$ DP, Rogus ], Duggirala R, Rich SS, Warram JH: A genome-wide linkage scan for genes controlling variation in urinary albumin excretion in type II diabetes. Kidney Int 2006, 69: I29-136.

87. Pezzolesi MG, Poznik GD, Mychaleckyj JC, Paterson AD, Barati MT, Klein JB, Ng DP, Placha G, Canani LH, Bochenski J, Waggott D, Merchant ML, Krolewski B, Mirea L, Wanic K, Katavetin P, Kure M, Wolkow P, Dunn JS, Smiles A, Walker WH, Boright AP, Bull SB, Doria A, Rogus JJ, Rich SS, Warram JH, Krolewski AS: Genomewide Association Scan for Diabetic Nephropathy Susceptibility Genes in Type I Diabetes Mellitus. Diabetes 2009.

88. Rogus JJ, Poznik GD, Pezzolesi MG, Smiles AM, Dunn J, Walker W, Wanic K, Moczulski D, Canani L, Araki S, Makita Y, Warram JH, Krolewski AS: High-density single nucleotide polymorphism genome-wide linkage scan for susceptibility genes for diabetic nephropathy in type I diabetes: discordant sibpair approach. Diabetes 2008, 57:2519-2526.

89. Gross JL, Zelmanovitz T, Moulin CC, De Mello V, Perassolo M, Leitao C, Hoefel A, Paggi A, Azevedo MJ: Effect of a chicken-based diet on renal function and lipid profile in patients with type 2 diabetes: a randomized crossover trial. Diabetes Care 2002, 25:645-65I.

90. Boright AP, Paterson AD, Mirea L, Bull SB, Mowjoodi A, Scherer SW, Zinman $B$ : Genetic variation at the ACE gene is associated with persistent microalbuminuria and severe nephropathy in type I diabetes: the DCCT/EDIC Genetics Study. Diabetes 2005, 54:1238-1244.

91. Brosius FC 3rd: New insights into the mechanisms of fibrosis and sclerosis in diabetic nephropathy. Rev Endocr Metab Disord 2008, 9:245-254.

92. Kramer CK, Leitao CB, Pinto LC, Bolson P, Boza J, Silveiro SP, Gross J, Canani LH: Risk Factors for Micro and Macrovascular Disease in black and white Patients with Type 2 Diabetes Mellitus. Revista Associação Médica Brasileira 2009 in press.

93. Fioretto $P$, Caramori ML, Mauer $M$ : The kidney in diabetes: dynamic pathways of injury and repair. The Camillo Golgi Lecture. Diabetologia 2007, 5 I:1347-1355.

94. Dronavalli S, Duka I, Bakris GL: The pathogenesis of diabetic nephropathy. Nat Clin Pract Endocrinol Metab 2008, 4:444-452.

95. Wolf G, Chen S, Ziyadeh FN: From the periphery of the glomerular capillary wall toward the center of disease: podocyte injury comes of age in diabetic nephropathy. Diabetes 2005, 54:1626-1634

96. Henegar JR, Bigler SA, Henegar LK, Tyagi SC, Hall JE: Functional and structural changes in the kidney in the early stages of obesity. J Am Soc Nephrol 2001, I 2:1211-1217.

97. Chagnac A, Weinstein T, Herman M, Hirsh J, Gafter U, Ori Y: The effects of weight loss on renal function in patients with severe obesity. J Am Soc Nephrol 2003, I4:| 480- | 486.

98. Zanatta CM, Gerchman F, Burttet L, Nabinger G, Jacques-Silva MC, Canani LH, Gross JL: Endothelin-I levels and albuminuria in patients with type 2 diabetes mellitus. Diabetes Res Clin Pract 2008, 80:299-304.

99. Sharma K, Eltayeb BO, McGowan TA, Dunn SR, Alzahabi B, Rohde R, Ziyadeh FN, Lewis EJ: Captopril-induced reduction of serum levels of transforming growth factor-betal correlates with long-term renoprotection in insulin-dependent diabetic patients. Am J Kidney Dis 1999, 34:818-823.

100. Hogan M, Cerami A, Bucala R: Advanced glycosylation endproducts block the antiproliferative effect of nitric oxide. Role in the vascular and renal complications of diabetes mellitus. J Clin Invest 1992, 90: I I I0- I I I 5.

I0I. Makita Z, Radoff S, Rayfield EJ, Yang Z, Skolnik E, Delaney V, Friedman $\mathrm{EA}$, Cerami A, Vlassara $\mathrm{H}$ : Advanced glycosylation end products in patients with diabetic nephropathy. N Engl J Med 1991, 325:836-842.

102. Cooper ME: Pathogenesis, prevention, and treatment of diabetic nephropathy. Lancet 1998, 352:213-219.

103. Yamagishi S, Fukami K, Ueda S, Okuda S: Molecular mechanisms of diabetic nephropathy and its therapeutic intervention. Curr Drug Targets 2007, 8:952-959.

104. Yamagishi S, Matsui T, Ueda S, Nakamura K, Imaizumi T: Advanced glycation end products (AGEs) and cardiovascular disease (CVD) in diabetes. Cardiovasc Hematol Agents Med Chem 2007, 5:236-240.

105. Casas JP, Chua W, Loukogeorgakis S, Vallance P, Smeeth L, Hingorani $A D$, MacAllister RJ: Effect of inhibitors of the renin-angiotensin system and other antihypertensive drugs on renal outcomes: systematic review and meta-analysis. Lancet 2005, 366:2026-2033.

106. Sarafidis PA, Stafylas PC, Kanaki Al, Lasaridis AN: Effects of reninangiotensin system blockers on renal outcomes and all-cause mortality in patients with diabetic nephropathy: an updated meta-analysis. Am J Hypertens 2008, 21 :922-929.

107. The effect of intensive treatment of diabetes on the development and progression of long-term complications in insulindependent diabetes mellitus. The Diabetes Control and Complications Trial Research Group. N Engl J Med 1993, 329:977-986.

108. Sustained effect of intensive treatment of type I diabetes mellitus on development and progression of diabetic nephropathy: the Epidemiology of Diabetes Interventions and Complications (EDIC) study. JAMA 2003, 290:2159-2I67.

109. Intensive blood-glucose control with sulphonylureas or insulin compared with conventional treatment and risk of complications in patients with type 2 diabetes (UKPDS 33). UK Prospective Diabetes Study (UKPDS) Group. Lancet 1998, 352:837-853.

I I0. Shichiri M, Kishikawa H, Ohkubo Y, Wake N: Long-term results of the Kumamoto Study on optimal diabetes control in type 2 diabetic patients. Diabetes Care 2000, 23(Suppl 2):B2I-29.

III. Holman RR, Paul SK, Bethel MA, Matthews DR, Neil HA: I0-year follow-up of intensive glucose control in type 2 diabetes. $N$ Engl J Med 2008, 359: I577-I 589.

I 12. Effect of intensive therapy on the development and progression of diabetic nephropathy in the Diabetes Control and Complications Trial. The Diabetes Control and Complications (DCCT) Research Group. Kidney Int 1995, 47: I703-1720.

I13. Intensive therapy and progression to clinical albuminuria in patients with insulin dependent diabetes mellitus and microalbuminuria. Microalbuminuria Collaborative Study Group, United Kingdom. BMJ 1995, 3 I I:973-977.

I 14. Duckworth W, Abraira C, Moritz T, Reda D, Emanuele N, Reaven PD, Zieve FJ, Marks J, Davis SN, Hayward R, Warren SR, Goldman S, McCarren M, Vitek ME, Henderson WG, Huang GD: Glucose control and vascular complications in veterans with type 2 diabetes. N Engl J Med 2009, 360: I 29-139.

I I5. Tight blood pressure control and risk of macrovascular and microvascular complications in type 2 diabetes: UKPDS 38. UK Prospective Diabetes Study Group. BMJ 1998, 3 I 7:703-7|3.

116. Chobanian AV, Bakris GL, Black HR, Cushman WC, Green LA, Izzo JL Jr, Jones DW, Materson BJ, Oparil S, Wright JT Jr, Roccella EJ: The Seventh Report of the Joint National Committee on Prevention, Detection, Evaluation, and Treatment of High Blood Pressure: the JNC 7 report. JAMA 2003, 289:2560-2572.

I 17. Hansson L, Zanchetti A, Carruthers SG, Dahlof B, Elmfeldt D, Julius $\mathrm{S}$, Menard J, Rahn $\mathrm{KH}$, Wedel $\mathrm{H}$, Westerling S: Effects of intensive blood-pressure lowering and low-dose aspirin in patients with hypertension: principal results of the Hypertension 
Optimal Treatment (HOT) randomised trial. HOT Study Group. Lancet 1998, 35 I:1755-1762.

118. Mogensen CE: Microalbuminuria and hypertension with focus on type I and type 2 diabetes. I Intern Med 2003, 254:45-66.

I 19. Bakris GL, Williams M, Dworkin L, Elliott WJ, Epstein M, Toto R, Tuttle K, Douglas J, Hsueh W, Sowers J: Preserving renal function in adults with hypertension and diabetes: $a$ consensus approach. National Kidney Foundation Hypertension and Diabetes Executive Committees Working Group. Am J Kidney Dis 2000, 36:646-66I.

120. Vijan S, Hayward RA: Treatment of hypertension in type 2 diabetes mellitus: blood pressure goals, choice of agents, and setting priorities in diabetes care. Ann Intern Med 2003, 138:593-602.

121. Bakris GL: A practical approach to achieving recommended blood pressure goals in diabetic patients. Arch Intern Med 200I, 16I:266|-2667.

122. Jerums G, Allen TJ, Campbell DJ, Cooper ME, Gilbert RE, Hammond Jj, Raffaele J, Tsalamandris C: Long-term comparison between perindopril and nifedipine in normotensive patients with type I diabetes and microalbuminuria. Am J Kidney Dis 200I, 37:890-899.

123. Lindholm LH, Ibsen $\mathrm{H}$, Dahlof $B$, Devereux RB, Beevers G, de Faire $U$, Fyhrquist F, Julius S, Kjeldsen SE, Kristiansson K, Lederballe-Pedersen O, Nieminen MS, Omvik P, Oparil S, Wedel H, Aurup P, Edelman J, Snapinn S: Cardiovascular morbidity and mortality in patients with diabetes in the Losartan Intervention For Endpoint reduction in hypertension study (LIFE): a randomised trial against atenolol. Lancet 2002, 359:1004-1010.

124. Ravid M, Brosh D, Levi Z, Bar-Dayan Y, Ravid D, Rachmani R: Use of enalapril to attenuate decline in renal function in normotensive, normoalbuminuric patients with type 2 diabetes mellitus. A randomized, controlled trial. Ann Intern Med 1998, 1 28:982-988.

125. Effects of ramipril on cardiovascular and microvascular outcomes in people with diabetes mellitus: results of the HOPE study and MICRO-HOPE substudy. Heart Outcomes Prevention Evaluation Study Investigators. Lancet 2000, 355:253-259.

126. Mauer M, Zinman B, Gardiner R, Suissa S, Sinaiko A, Strand T, Drummond K, Donnelly S, Goodyer P, Gubler MC, Klein R: Renal and retinal effects of enalapril and losartan in type I diabetes. $N$ Engl I Med 2009, 36 I:40-5I.

127. Viberti G, Wheeldon NM: Microalbuminuria reduction with valsartan in patients with type 2 diabetes mellitus: a blood pressure-independent effect. Circulation 2002, 106:672-678.

128. Should all patients with type I diabetes mellitus and microalbuminuria receive angiotensin-converting enzyme inhibitors? A meta-analysis of individual patient data. Ann Intern Med 200I, I34:370-379.

129. Parving HH, Lehnert H, Brochner-Mortensen J, Gomis R, Andersen S, Arner $P$ : The effect of irbesartan on the development of diabetic nephropathy in patients with type 2 diabetes. N Engl J Med 200I, 345:870-878.

130. Parving HH, Andersen AR, Smidt UM, Svendsen PA: Early aggressive antihypertensive treatment reduces rate of decline in kidney function in diabetic nephropathy. Lancet 1983, I: I I75-1179.

131. Rossing P, Hommel E, Smidt UM, Parving HH: Reduction in albuminuria predicts a beneficial effect on diminishing the progression of human diabetic nephropathy during antihypertensive treatment. Diabetologia 1994, 37:5 II-5 I6.

132. Peterson JC, Adler S, Burkart JM, Greene T, Hebert LA, Hunsicker LG, King AJ, Klahr S, Massry SG, Seifter JL: Blood pressure control, proteinuria, and the progression of renal disease. The Modification of Diet in Renal Disease Study. Ann Intern Med 1995, 1 23:754-762.

133. Lewis EJ, Hunsicker LG, Bain RP, Rohde RD: The effect of angiotensin-converting-enzyme inhibition on diabetic nephropathy. The Collaborative Study Group. N Engl ] Med 1993, 329: 1456-I 462

134. Brenner BM, Cooper ME, de Zeeuw D, Keane WF, Mitch WE, Parving HH, Remuzzi G, Snapinn SM, Zhang Z, Shahinfar S: Effects of losartan on renal and cardiovascular outcomes in patients with type 2 diabetes and nephropathy. N Engl I Med 200I, 345:86I-869.
135. Lewis EJ, Hunsicker LG, Clarke WR, Berl T, Pohl MA, Lewis JB, Ritz E, Atkins RC, Rohde R, Raz I: Renoprotective effect of the angiotensin-receptor antagonist irbesartan in patients with nephropathy due to type 2 diabetes. N Engl J Med 200I, 345:85I-860.

136. Andersen S, Jacobsen P, Tarnow L, Rossing P, Juhl TR, Parving HH: Time course of the antiproteinuric and antihypertensive effect of losartan in diabetic nephropathy. Nephrol Dial Transplant 2003, 18:293-297.

137. Weinberg MS, Kaperonis N, Bakris GL: How high should an ACE inhibitor or angiotensin receptor blocker be dosed in patients with diabetic nephropathy? Curr Hypertens Rep 2003, 5:4I 8-425.

138. Bakris GL, Weir MR: Angiotensin-converting enzyme inhibitorassociated elevations in serum creatinine: is this a cause for concern? Arch Intern Med 2000, 160:685-693.

139. Nicholls AJ: The impact of atherosclerotic renovascular disease on diabetic renal failure. Diabet Med 2002, 19:889-894.

140. Mogensen CE, Neldam S, Tikkanen I, Oren S, Viskoper R, Watts RW, Cooper ME: Randomised controlled trial of dual blockade of renin-angiotensin system in patients with hypertension, microalbuminuria, and non-insulin dependent diabetes: the candesartan and lisinopril microalbuminuria (CALM) study. BMJ 2000, 32 I: | 1440-I444.

141. Rosner MH, Okusa MD: Combination therapy with angiotensin-converting enzyme inhibitors and angiotensin receptor antagonists in the treatment of patients with type 2 diabetes mellitus. Arch Intern Med 2003, 163:1025-1029.

142. Mann JF, Schmieder RE, McQueen M, Dyal L, Schumacher H, Pogue J, Wang X, Maggioni A, Budaj A, Chaithiraphan S, Dickstein K, Keltai M, Metsarinne K, Oto A, Parkhomenko A, Piegas LS, Svendsen TL, Teo KK, Yusuf S: Renal outcomes with telmisartan, ramipril, or both, in people at high vascular risk (the ONTARGET study): a multicentre, randomised, double-blind, controlled trial. Lancet 2008, 372:547-553.

143. Fried LF, Duckworth W, Zhang JH, O'Connor T, Brophy M, Emanuele N, Huang GD, McCullough PA, Palevsky PM, Seliger S, Warren SR, Peduzzi P: Design of combination angiotensin receptor blocker and angiotensin-converting enzyme inhibitor for treatment of diabetic nephropathy (VA NEPHRON-D). Clin J Am Soc Nephrol 2009, 4:36I-368.

144. Yoneda T, Takeda Y, Usukura M, Oda N, Takata H, Yamamoto $Y$, Karashima S, Yamagishi M: Aldosterone breakthrough during angiotensin II receptor blockade in hypertensive patients with diabetes mellitus. Am J Hypertens 2007, 20:1329-1333.

145. Sato A, Hayashi K, Naruse M, Saruta T: Effectiveness of aldosterone blockade in patients with diabetic nephropathy. Hypertension 2003, 41:64-68.

146. Navaneethan SD, Nigwekar SU, Sehgal AR, Strippoli GF: Aldosterone antagonists for preventing the progression of chronic kidney disease: a systematic review and meta-analysis. Clin J Am Soc Nephrol 2009, 4:542-55I.

147. Parving HH, Persson F, Lewis JB, Lewis EJ, Hollenberg NK: Aliskiren combined with losartan in type 2 diabetes and nephropathy. N Engl J Med 2008, 358:2433-2446.

148. Parving HH, Brenner BM, McMurray J], de Zeeuw D, Haffner SM, Solomon SD, Chaturvedi N, Ghadanfar M, Weissbach N, Xiang Z, Armbrecht J, Pfeffer MA: Aliskiren Trial in Type 2 Diabetes Using Cardio-Renal Endpoints (ALTITUDE): rationale and study design. Nephrol Dial Transplant 2009, 24:1663-1671.

149. Bailey C], Turner RC: Metformin. N Engl ] Med 1996, 334:574-579.

150. Rachmani R, Slavachevski I, Levi Z, Zadok B, Kedar Y, Ravid M: Metformin in patients with type 2 diabetes mellitus: reconsideration of traditional contraindications. Eur J Intern Med 2002, 13:428.

15I. Shaw JS, Wilmot RL, Kilpatrick ES: Establishing pragmatic estimated GFR thresholds to guide metformin prescribing. Diabet Med 2007, 24: II60-1163.

152. Inzucchi SE: Oral antihyperglycemic therapy for type 2 diabetes: scientific review. JAMA 2002, 287:360-372.

153. Charpentier G, Riveline JP, Varroud-Vial M: Management of drugs affecting blood glucose in diabetic patients with renal failure. Diabetes Metab 2000, 26(Suppl 4):73-85.

154. Harrower AD: Pharmacokinetics of oral antihyperglycaemic agents in patients with renal insufficiency. Clin Pharmacokinet 1996, 31:111-119. 
155. Hasslacher C: Safety and efficacy of repaglinide in type 2 diabetic patients with and without impaired renal function. Diabetes Care 2003, 26:886-891.

156. Del Prato S, Heine RJ, Keilson L, Guitard C, Shen SG, Emmons RP: Treatment of patients over 64 years of age with type 2 diabetes: experience from nateglinide pooled database retrospective analysis. Diabetes Care 2003, 26:2075-2080.

157. Schumacher S, Abbasi I, Weise D, Hatorp V, Sattler K, Sieber J, Hasslacher C: Single- and multiple-dose pharmacokinetics of repaglinide in patients with type 2 diabetes and renal impairment. Eur J Clin Pharmacol 200I, 57:147-I52.

158. Nagai T, Imamura M, lizuka K, Mori M: Hypoglycemia due to nateglinide administration in diabetic patient with chronic renal failure. Diabetes Res Clin Pract 2003, 59:191-194.

159. Inoue T, Shibahara N, Miyagawa K, Itahana R, Izumi M, Nakanishi T, Takamitsu Y: Pharmacokinetics of nateglinide and its metabolites in subjects with type 2 diabetes mellitus and renal failure. Clin Nephrol 2003, 60:90-95.

160. Reuser AJ, Wisselaar HA: An evaluation of the potential sideeffects of alpha-glucosidase inhibitors used for the management of diabetes mellitus. Eur J Clin Invest 1994, 24(Suppl $3): 19-24$.

161. Szeto CC, Li PK. Antiproteinuric and anti-inflammatory effects of thiazolidinedione. Nephrology (Carlton) 2008, 13:53-57.

162. Iglesias P, Diez J]: Peroxisome proliferator-activated receptor gamma agonists in renal disease. Eur J Endocrinol 2006, 154:613-621.

163. Bakris G, Viberti G, Weston WM, Heise M, Porter LE, Freed MI: Rosiglitazone reduces urinary albumin excretion in type II diabetes. J Hum Hypertens 2003, 17:7-12.

164. Kincaid-Smith P, Fairley KF, Farish S, Best JD, Proietto J: Reduction of proteinuria by rosiglitazone in non-diabetic renal disease. Nephrology (Carlton) 2008, 13:58-62.

165. Pistrosch F, Herbrig K, Kindel B, Passauer J, Fischer S, Gross P: Rosiglitazone improves glomerular hyperfiltration, renal endothelial dysfunction, and microalbuminuria of incipient diabetic nephropathy in patients. Diabetes 2005, 54:2206-22II.

166. Schwartz AV, Sellmeyer DE, Vittinghoff E, Palermo L, Lecka-Czernik B, Feingold KR, Strotmeyer ES, Resnick HE, Carbone L, Beamer BA, Park SW, Lane NE, Harris TB, Cummings SR: Thiazolidinedione use and bone loss in older diabetic adults. J Clin Endocrinol Metab 2006, $91: 3349-3354$

167. Meier C, Kraenzlin ME, Bodmer M, Jick SS, Jick H, Meier CR: Use of thiazolidinediones and fracture risk. Arch Intern Med 2008, 1 68:820-825.

168. Scherbaum WA: Do patients with type 2 diabetes on peritoneal dialysis need less insulin if they are given rosiglitazone? Nat Clin Pract Nephrol 2006, 2:312-313.

169. Farkouh ME, Fuster V: Meta-analysis of small trials: proceed with caution. Nat Clin Pract Nephrol 2008, 4: II 5

170. Loke YK, Singh S, Furberg CD: Long-term use of thiazolidinediones and fractures in type 2 diabetes: a meta-analysis. CMAJ 2009, 180:32-39.

17I. Bergman AJ, Cote J, Yi B, Marbury T, Swan SK, Smith W, Gottesdiener K, Wagner J, Herman GA: Effect of renal insufficiency on the pharmacokinetics of sitagliptin, a dipeptidyl peptidase-4 inhibitor. Diabetes Care 2007, 30:1862-1864.

172. Chan JC, Scott R, Arjona Ferreira JC, Sheng D, Gonzalez E, Davies MJ, Stein PP, Kaufman KD, Amatruda JM, Williams-Herman D: Safety and efficacy of sitagliptin in patients with type 2 diabetes and chronic renal insufficiency. Diabetes Obes Metab 2008 , 10:545-555.

173. Linnebjerg H, Kothare PA, Park S, Mace K, Reddy S, Mitchell M, Lins $R$ : Effect of renal impairment on the pharmacokinetics of exenatide. Br J Clin Pharmacol 2007, 64:3 17-327.

174. Pedrini MT, Levey AS, Lau J, Chalmers TC, Wang PH: The effect of dietary protein restriction on the progression of diabetic and nondiabetic renal diseases: a meta-analysis. Ann Intern Med 1996, I 24:627-632.

175. Hansen HP, Tauber-Lassen E, Jensen BR, Parving HH: Effect of dietary protein restriction on prognosis in patients with diabetic nephropathy. Kidney Int 2002, 62:220-228.

176. Pijls LT, de Vries H, van Eijk JT, Donker AJ: Protein restriction, glomerular filtration rate and albuminuria in patients with type 2 diabetes mellitus: a randomized trial. Eur J Clin Nutr 2002, 56: $1200-1207$
177. Pan Y, Guo LL, Jin HM: Low-protein diet for diabetic nephropathy: a meta-analysis of randomized controlled trials. Am J Clin Nutr 2008, 88:660-666.

178. de Mello VD, Zelmanovitz T, Perassolo MS, Azevedo MJ, Gross JL: Withdrawal of red meat from the usual diet reduces albuminuria and improves serum fatty acid profile in type $\mathbf{2}$ diabetes patients with macroalbuminuria. Am J Clin Nutr 2006, 83: $1032-1038$.

179. de Mello VD, Zelmanovitz T, Azevedo MJ, de Paula TP, Gross JL: Long-term effect of a chicken-based diet versus enalapril on albuminuria in type 2 diabetic patients with microalbuminuria. I Ren Nutr 2008, 18:440-447.

180. Colhoun HM, Betteridge DJ, Durrington PN, Hitman GA, Neil HA, Livingstone SJ, Charlton-Menys V, Demicco DA, Fuller JH: Effects of Atorvastatin on Kidney Outcomes and Cardiovascular Disease in Patients With Diabetes: An Analysis From the Collaborative Atorvastatin Diabetes Study (CARDS). Am J Kidney Dis 2009.

18I. Gaede P, Vedel P, Larsen N, Jensen GV, Parving HH, Pedersen O: Multifactorial intervention and cardiovascular disease in patients with type 2 diabetes. N Engl J Med 2003, 348:383-393.

Publish with Biomed Central and every scientist can read your work free of charge

"BioMed Central will be the most significant development for disseminating the results of biomedical research in our lifetime. "

Sir Paul Nurse, Cancer Research UK

Your research papers will be:

- available free of charge to the entire biomedical community

- peer reviewed and published immediately upon acceptance

- cited in PubMed and archived on PubMed Central

- yours - you keep the copyright
BioMedcentral 